\title{
Amide Synthesis through the In Situ Generation of Chloro- and Imido-Phosphonium Salts
}

\author{
Charles D. Irving, Jack T. Floreancig, and Sébastien Laulhé*
}

Cite This: https://dx.doi.org/10.1021/acsomega.0c02309

Read Online

ABSTRACT: We describe a methodology for the amidation of carboxylic acids by generating phosphonium salts in situ from $\mathrm{N}$-chlorophthalimide and triphenylphosphine. Aliphatic, benzylic, and aromatic carboxylic acids can be transformed into their amide counter parts using primary and secondary amines. This functional group interconversion is achieved at room temperature in good to excellent yields. Mechanistic work shows the

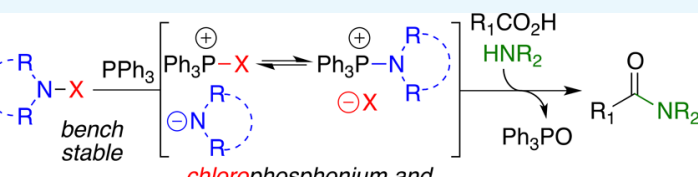

$$
\begin{aligned}
& \text { chlorophosphonium and }
\end{aligned}
$$
in situ formation of chloro- and imido-phosphonium salts that react as activating agents for carboxylic acids and generate an acyloxyphosphonium species.

\section{INTRODUCTION}

Amides are important functional groups in organic chemistry due to their relevance in biological processes (proteins, peptides) and their presence in a diverse set of bioactive compounds. ${ }^{1}$ The bioactivity and applications of such compounds are broad and range from pharmaceuticals ${ }^{2}$ and pesticides ${ }^{3}$ to polymers and adhesives. ${ }^{4}$ Additionally, according to a recent analysis of the literature, ${ }^{5}$ amide bond syntheses are the most frequently cited synthetic methodologies in medicinal chemistry. The most common approach to access amides involves the activation of carboxylic acids through the use of coupling reagents. ${ }^{6}$ The native chemical ligation has also been employed successfully for larger polypeptides and protein syntheses. $^{7}$ Such state-of-the-art methodologies gained significant traction in the peptide field in parallel with the development of solid-phase synthesis. ${ }^{8}$ Recently, catalytic methods for activating carboxylic acids have also been developed using boronic acid catalysts.'

Yet, it is often the case that simple amides resist formation, which has led to the development of ever more complex and toxic coupling reagents and methods. ${ }^{10}$ Both carbodiimide ${ }^{11}$ and phosphonium salt reagents ${ }^{12}$ are among the most commonly used coupling agents due to their high reactivity and ability to minimize epimerization (Figure 1A,B). Unfortunately, carbodiimide reagents have to be handled with caution since they can cause severe allergic skin reactions and decompose with atmospheric moisture. ${ }^{6}$ Similarly, phosphonium salt reagents are highly moisture sensitive, and they produce supra-stoichiometric amounts of carcinogenic hexamethylphosphoramide (HMPA). ${ }^{12 a, b}$ Some also contain high-energy benzotriazole moieties, ${ }^{12 c, d}$ which represent an explosion hazard $^{13 a}$ (Figure 1A,B) and, in some cases, lead to an unwanted nucleophilic competitor. ${ }^{13 \mathrm{~b}}$

In our recent work, we observed that $\mathrm{N}$-chloroimides could be activated to perform radical reactions using lithium tertbutoxide. ${ }^{14}$ Presumably, $\mathrm{N}$-chloroimides can react with strong

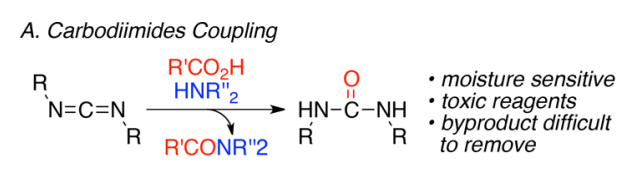

B. Phosphonium Salts
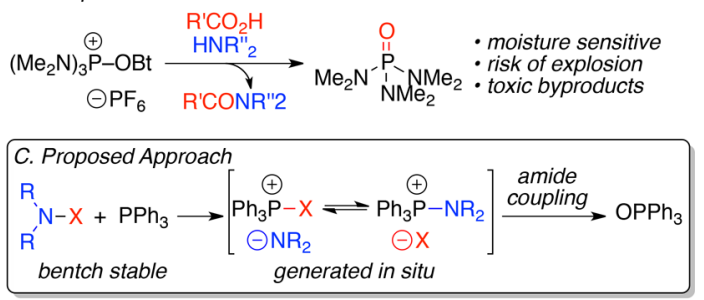

Figure 1. Selected examples of coupling technologies.

nucleophiles via halogen bonding interactions ${ }^{15}$ and generate reactive species with new or unexplored reactivity. We recognized the possibility of generating phosphonium salts from bench-stable reagents to produce coupling agents in situ (Figure 1C), therefore minimizing current drawbacks such as reagent stability.

In the past decade, various reports have been published generating phosphonium salts in situ from activated halogen sources. ${ }^{16}$ Indeed, the use of $\mathrm{I}_{2},{ }^{16 a} \mathrm{~d}$ 2,4,4,6-tetrabromo-2,5cyclohexadienone, ${ }^{16 \mathrm{~b}}$ and 2,4,6-trichloro-1,3,5-triazine ${ }^{16 \mathrm{c}}$ in the presence of $\mathrm{PPh}_{3}$ has been used as means to perform amide bond couplings. Similar strategies using $\mathrm{N}$-halogenated reagents have been developed. ${ }^{17}$ For instance, in spite of its

Received: May 17, 2020

Accepted: June 5, 2020 
high cost, $N$-chlorobenzotriazole has been used to generate phosphonium salts in situ. ${ }^{17 a}$ The use of $N$-haloimides has been explored as a more cost-effective alternative by Prakash et al. ${ }^{17 \mathrm{~b}}$ and Tang et al. ${ }^{17 \mathrm{c}}$ using $\mathrm{N}$-bromosuccinimide (NBS) and selectfluor to generate acyl fluorides. While the use of $N$ chlorosuccinimide (NCS) has been reported to generate amides from carboxylic acids, ${ }^{17 \mathrm{~d}}$ this method requires multiple steps, cooling, and premixing to avoid rapid decompositions for the active species. Additionally, none of these reports ${ }^{16,17}$ provided a detailed characterization of the reactive phosphonium species to support a detailed mechanism.

The methodology we have developed generates amides through the simple mixture of $N$-chlorophthalimide in the presence of $\mathrm{PPh}_{3}$ and the desired carboxylic acid and amine reagents to couple. Our ${ }^{31} \mathrm{P} \mathrm{NMR}$ experiments show that mixing $N$-chloroimides in the presence of $\mathrm{PPh}_{3}$ generates two phosphonium salts (chloro- and imido-phosphonium species) that efficiently activate carboxylic acids toward amide bond formation (Figure 1C). Our work is the first to observe and characterize this imido-phosphonium intermediate using ${ }^{31} \mathrm{P}$ NMR and high-resolution mass-spectrometry (HR-MS). This observation provides more detailed insights into the mechanism and can help design better methodologies involving in situ formation of phosphonium salts.

\section{RESULTS AND DISCUSSION}

We began our investigation using benzoic acid $(1 a)$ as our carboxylic acid substrate and both benzylamine $(2 a)$ and benzylmethylamine $(\mathbf{2 b})$ as $\mathrm{I}^{\circ}$ and $\mathrm{II}^{\circ}$ amine substrates. Optimal reaction conditions (Table 1 , entry 1 ) were obtained using 1.5 equiv of $\mathrm{PPh}_{3}$ and $\mathrm{N}$-chlorophthalimide (NCPhth) at room temperature for $12 \mathrm{~h}$. Primary amine $2 a$ consistently afforded the corresponding amide in better yield than secondary amine $2 \boldsymbol{b}$. Presumably, the increase in steric hindrance is responsible for the reduced yield. The use of other commercially available $N$-haloimides such as NCS, NBS,

Table 1. Reaction Optimization ${ }^{a}$

\begin{tabular}{|c|c|c|c|c|}
\hline & ${ }_{1 a}^{\mathrm{O}}$ & $\begin{array}{l}\mathrm{Ph}_{\mathrm{H}} \widehat{N}^{-\mathrm{R}} \\
2 \boldsymbol{a}(\mathrm{R}=\mathrm{H}) \\
2 \boldsymbol{b}(\mathrm{R}=\mathrm{Me})\end{array}$ & $\frac{\mathrm{XNR}_{2}+\mathrm{PR}_{3}}{\text { solvent, it }}$ & 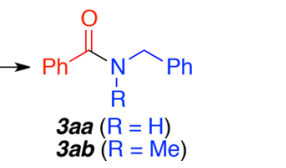 \\
\hline entry & $\mathrm{PR}_{3}$ & $\mathrm{XNR}_{2}$ & solvent & yield $^{b}(3 a a / 3 a b)$ \\
\hline 1 & $\mathrm{PPh}_{3}$ & NCPhth & toluene & $94 \%(83 \%)^{c} / 63 \%$ \\
\hline 2 & $\mathrm{PPh}_{3}$ & NCS & toluene & $74 \%$ / 26\% \\
\hline 3 & $\mathrm{PPh}_{3}$ & NBS & toluene & $66 \% / 54 \%$ \\
\hline 4 & $\mathrm{PPh}_{3}$ & NIS & toluene & $59 \%$ / 59\% \\
\hline 5 & & NCPhth & toluene & $6 \% / 0 \%$ \\
\hline 6 & $\mathrm{PPh}_{3}$ & & toluene & $2 \% / 2 \%$ \\
\hline 7 & $\mathrm{PCy}_{3}$ & NCPhth & toluene & $85 \%$ / $43 \%$ \\
\hline 8 & $\mathrm{P}(n-\mathrm{Bu})_{3}$ & NCPhth & toluene & $57 \% / 42 \%$ \\
\hline 9 & $\mathrm{P}(o-\text { tol })_{3}$ & NCPhth & toluene & $34 \%$ / $27 \%$ \\
\hline 10 & $\mathrm{PPh}_{3}$ & NCPhth & $\mathrm{CH}_{2} \mathrm{Cl}_{2}$ & $91 \% / 60 \%$ \\
\hline 11 & $\mathrm{PPh}_{3}$ & NCPhth & EtOAc & $81 \%$ / $59 \%$ \\
\hline 12 & $\mathrm{PPh}_{3}$ & NCPhth & $\mathrm{CH}_{3} \mathrm{CN}$ & $90 \% / 72 \%(65 \%)^{c}$ \\
\hline
\end{tabular}

${ }^{a}$ All reactions were performed using $1 \mathrm{~mL}$ of anhydrous, solvent, $0.164 \mathrm{mmol}$ (1 equiv) of benzoic acid, $0.246 \mathrm{mmol}$ (1.5 equiv) of $N$ haloimide and phosphine reagents, and $0.492 \mathrm{mmol}$ (3 equiv) of amine substituent. The reactions were performed at room temperature $\left(24{ }^{\circ} \mathrm{C}\right)$ with constant stirring for $12 \mathrm{~h} .{ }^{b}$ NMR yield obtained using dibromomethane as the internal standard. ${ }^{c}$ Isolated yield. and $\mathrm{N}$-iodosuccinimide (NIS) also generated the desired products but in lower yields (Table 1, entries 2-4). Importantly, control experiments in the absence of phosphine or $\mathrm{N}$-haloimide reagents did not provide the desired amides in significant yields (entries 5 and 6). Screening of other phosphines as suitable activators of $N$-chlorophthalimide (Table 1, entries 7-9) gave mixed results, while tricyclohexylphosphine $\left(\mathrm{PCy}_{3}\right.$, entry 7$)$ did afford product $3 a a$ in good yields (85\%), the formation of product $3 a b$ seems to be lackluster $(43 \%)$. Similarly, tributylphosphine $\left(\mathrm{P}(n-\mathrm{Bu})_{3}\right)$ and tri $(o$-tolyl $)$ phosphine $\left(\mathrm{P}(o \text {-tol })_{3}\right)$ proceeded through the reaction but with lower yields (entries 8 and 9). The increase in the Tolman angle ${ }^{18}$ from $\mathrm{PPh}_{3}\left(145^{\circ}\right), \mathrm{PCy}_{3}\left(179^{\circ}\right)$, and $\mathrm{P}(\text { o-tol })_{3}\left(194^{\circ}\right)$ may be preventing the efficient nucleophilic attack of the $N$-chlorophthalimide. Finally, the reaction also proceeds efficiently in a variety of anhydrous polar aprotic solvents such as dichloromethane, ethyl acetate, and acetonitrile for the formation of product 3aa (entries 1012). Product $3 a b$ is also formed under those conditions but anhydrous acetonitrile provides the best yields at $72 \%$ (entry 12).

With the established optimal conditions in hand, we proceeded to first examine the scope of amine substrates 2 compatible with our reaction conditions. Gratifyingly, the protocol was efficient for the amidation of a diverse set of $\mathrm{I}^{\circ}$ and $\mathrm{II}^{\circ}$ amines (Figure 2). Our protocol was effective for a

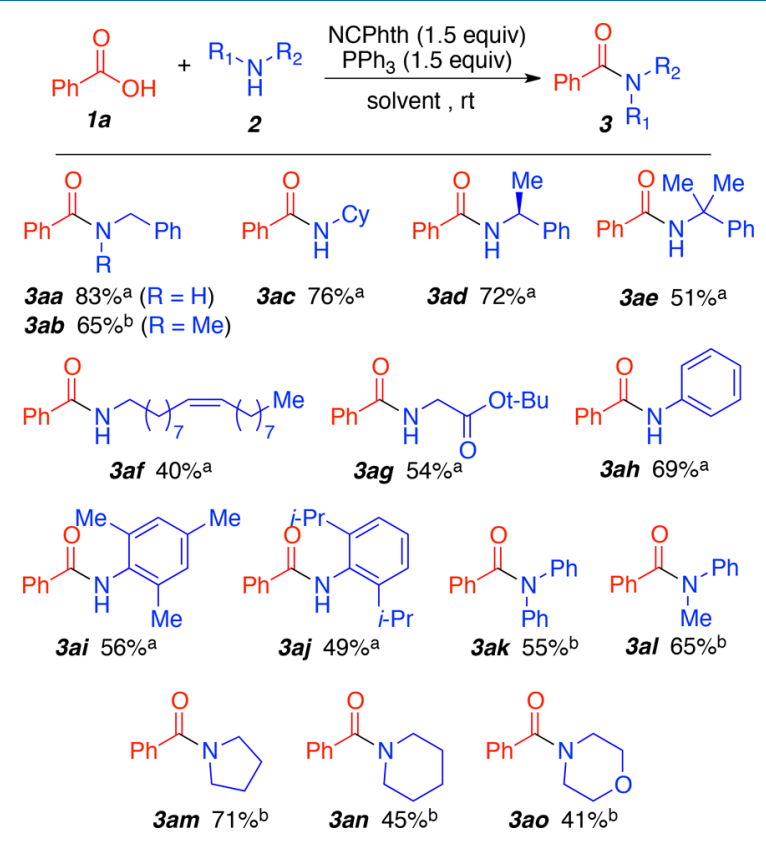

Figure 2. Reaction scope for amines. All reactions were performed in $3 \mathrm{~mL}$ of solvent, $1 \boldsymbol{a}(0.82 \mathrm{mmol}) 2(2.4 \mathrm{mmol})$, NCPhth $(1.2 \mathrm{mmol})$, and $\mathrm{PPh}_{3}(1.2 \mathrm{mmol})$ (unless otherwise specified (see Experimental Section). ${ }^{a}$ Reactions performed using toluene as the solvent. ${ }^{b}$ Reactions performed using acetonitrile as the solvent. Yields reported are isolated yields.

variety of aliphatic amines $(3 a a-3 a f)$ with yields ranging from moderate to excellent. However, the increase of steric hindrance in the $\alpha$-position of $\mathrm{I}^{\circ}$ alkyl amines has a deleterious effect on yield. Indeed, coupling products $3 a d$ through $3 a e$ were obtained in lower yields as more substituents were added in the $\alpha$-position. The alkene functionality in oleylamine is tolerated (product 3af), but isolation of the corresponding 
amide was challenging using column chromatography. Bulky esters that do not readily transamidate are also tolerated and provided product $3 \mathrm{ag}$ in $54 \%$ yield (Figure 2). Interestingly, both $\mathrm{I}^{\circ}$ and $\mathrm{II}^{\circ}$ aniline derivatives also afforded the corresponding amides $(\mathbf{3 a h}-\mathbf{3 a j})$ in moderate to good isolated yields. While aniline reacted in $69 \%$ yield, increasing sterics around the nitrogen led to erosion in yield with $3 a i$ and $3 a j$ providing the amides in 56 and 49\% yields, respectively. Yet, our protocol seems more efficient at coupling sterically bulky aniline derivatives compared to analogous protocols. ${ }^{16,17 a}$

Additionally, this methodology possesses a wider scope with respect to secondary amine substrates than similar procedures. ${ }^{16}$ Reactions using diphenylamine and $N$-methylaniline worked in moderate yields at 55 and $65 \%$, respectively. Cyclic $\mathrm{II}^{\circ}$ amines also amidated in moderate to good yields with pyrrolidine affording product $3 \mathrm{am}$ in $71 \%$ yield, piperidine affording product $3 a n$ in $45 \%$ yield, and morphiline generating product $3 a o$ in $41 \%$ yield (Figure 2 ).

Next, we examined the compatibility of our optimal reaction conditions with different carboxylic acids $(\mathbf{1} b-\mathbf{1} k)$ and using benzyl amine $2 a$ and benzylmethylamine $2 b$ as the amine substrates. As shown in Figure 3, the method enabled the

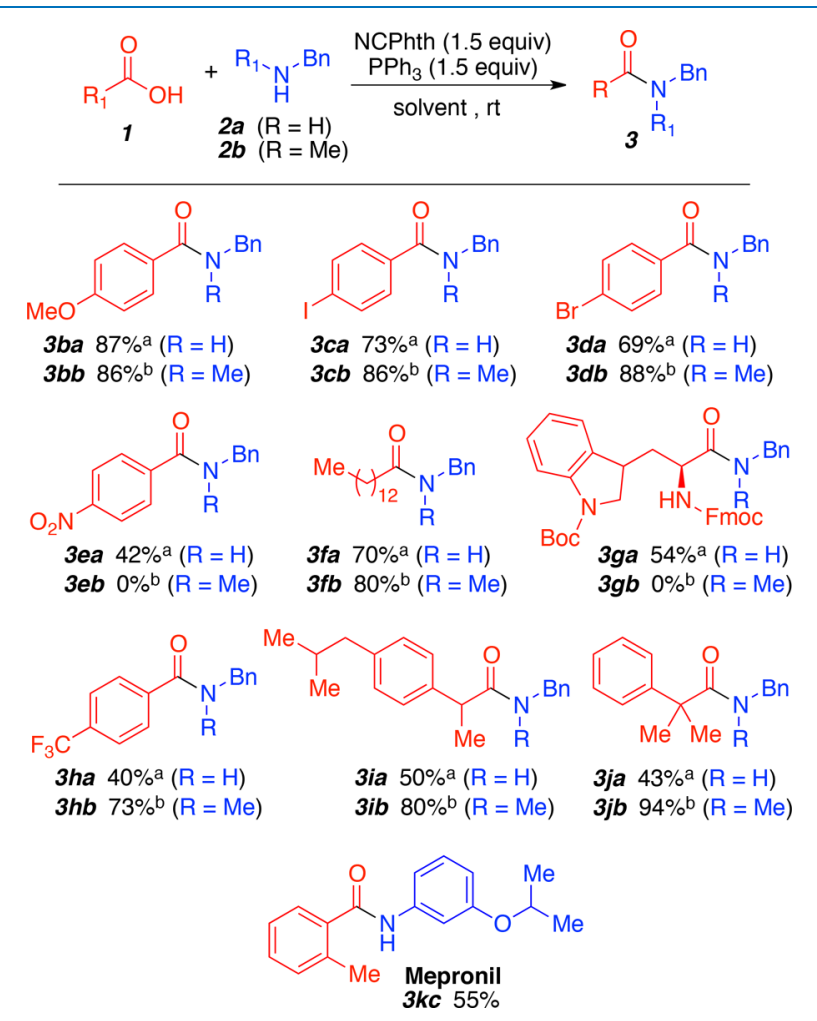

Figure 3. Scope of carboxylic acid substrates. All reactions were performed in $3 \mathrm{~mL}$ of solvent, $\boldsymbol{1}$ ( $100 \mathrm{mg}$ ), $2 \boldsymbol{a}$ ( 3 equiv), $\boldsymbol{2} \boldsymbol{b}$ ( 3 equiv), NCphth (1.5 equiv), $\mathrm{PPh}_{3}$ (1.5 equiv). ${ }^{a}$ Reactions performed using toluene as the solvent. ${ }^{b}$ Reactions performed using acetonitrile as the solvent. Yields reported are isolated yields.

amidation of electron rich $(3 \boldsymbol{b a} / \boldsymbol{b}(87 \% / 86 \%))$ and electron poor ( $3 e \boldsymbol{a ~} 42 \%$ and $3 \mathbf{h a / b}(40 \% / 73 \%))$ aryl carboxylic acids in good to excellent yields. However, reactivity varied significantly among substrates, and secondary amines seem to sometimes fail to perform the transformation (3eb). Aryl halides provided the desired products in good to excellent yields for both $\mathrm{I}^{\circ}$ and $\mathrm{II}^{\circ}$ amines (3da, 3db). Alkyl carboxylic acids were also well tolerated and afforded products in moderate to excellent yields $(3 f a / b, 3 i a / b$, and $3 j a / b)$. Protected tryptophan amino acid was also converted into the corresponding amide in moderate yields when coupling with primary amines ( $3 g a 54 \%$ yield) but failed to provide the desired product with secondary amines $(3 \boldsymbol{g} \boldsymbol{b})$ most likely due to amine-induced Fmoc deprotection. Finally, our method enabled the synthesis of antifungal agrochemical Mepronil 3lc from the ortho-substituted carboxylic acid in 55\% yield in milder conditions than current approaches. ${ }^{16 \mathrm{~d}, 20}$

Another possible transformation we envisioned with our methodology was the direct formation of acyl phthalimides from carboxylic acids in the cases where amine coupling partners are not added to the reaction mixture (Figure 4). Acyl

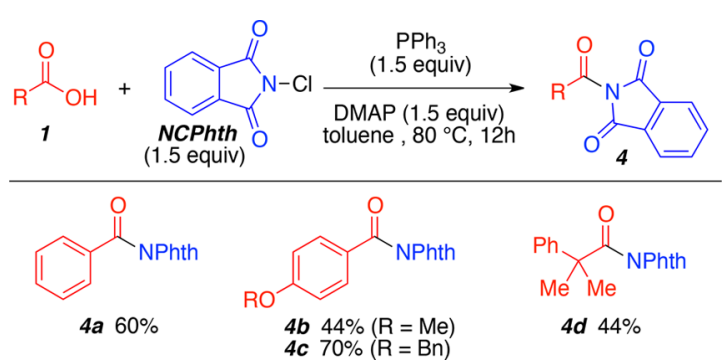

Figure 4. Synthesized acyl phthalimides. All reactions were run in 3 $\mathrm{mL}$ of solvent, carboxylic acid (100 mg), NCPhth (1.5 equiv), PPh3 (1.5 equiv), and DMAP (1.5 equiv).

phthalimides are important precursors for the formation of the biologically active $\mathrm{N}$-, $\mathrm{O}$-acetal motifs found in several natural products. ${ }^{19}$ Acyl phthalimides also hold merit as potential anxiolytic, antibacterial, and antifungal compounds. ${ }^{20}$ Synthetic applications have also been explored using acyl imides as efficient acylating and coupling agents in metal-catalyzed reactions. ${ }^{21}$ Lastly, acyl imides have been used as transamidation agents in metal-free methodologies. ${ }^{22}$

After a brief optimization, we found that mixing $\mathrm{N}$ chlorophthalimide and $\mathrm{PPh}_{3}$ in the presence of carboxylic acids and 4-dimethylaminopyridine (DMAP) at $80{ }^{\circ} \mathrm{C}$ in toluene afforded the best yields. The use of heat is required here to promote the nucleophilic attack of the phthalimide unto the activated carboxylic acid. The use of a nonnucleophilic base was also required to ensure deprotonation of the phthalimide.

Figure 4 shows the scope of carboxylic acids that were used to acylate phthalimide. Overall, our conditions were found to generate the desired products albeit in moderate yields. Electron-neutral and electron-rich carboxylic acids $(4 a-4 c)$ reacted to afford the acyl phthalimide adducts in 60,44 , and $70 \%$ yield, respectively. It should be noted that this method did not work with a substrate bearing an electron-withdrawing group. Aliphatic carboxylic acids were also transformed in moderate yields $(4 d)$.

To gain insights into the mechanism of the amidation reaction, we carried out a series of ${ }^{31} \mathrm{P}$ NMR experiments with the hope of identifying and characterizing the reactive intermediates in this methodology. To our surprise, ${ }^{31} \mathrm{P}$ NMR experiments showed that $N$-chlorophthalimide and triphenylphosphine react together to form two phosphonium salt species: (i) a chloro-phosphonium salt at $64 \mathrm{ppm}$ and (ii) an imido-phosphonium salt at $32 \mathrm{ppm}$ (Figure 5). Triphenylphosphine oxide and unreacted $\mathrm{Ph}_{3} \mathrm{P}$ were also present. 

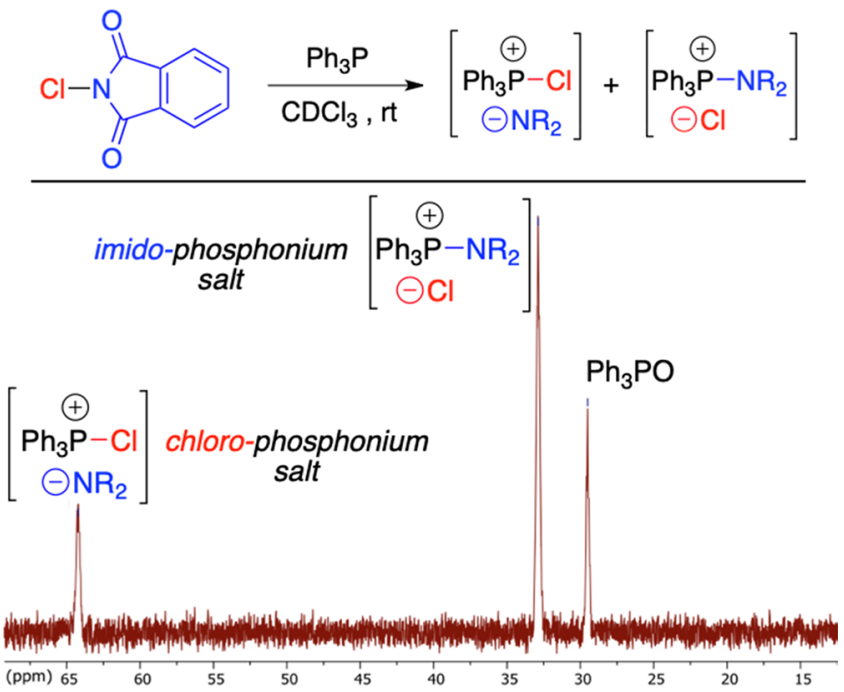

Figure 5. In situ generated phosphonium salts observed via ${ }^{31} \mathrm{P}$ NMR. Reaction mixture consisted of triphenylphosphine $(0.08 \mathrm{mmol}, 1$ equiv) and NCPhth (0.08 mmol, 1 equiv) dissolved in $\mathrm{CDCl}_{3}$.

We confirmed the identity of the chloro-phosphonium salt at $64 \mathrm{ppm}$ through its synthesis using oxalyl chloride ${ }^{23}$ and comparing it with different $\mathrm{N}$-chlorimides (Figure 6). These experiments further emphasized our hypothesis that the peak
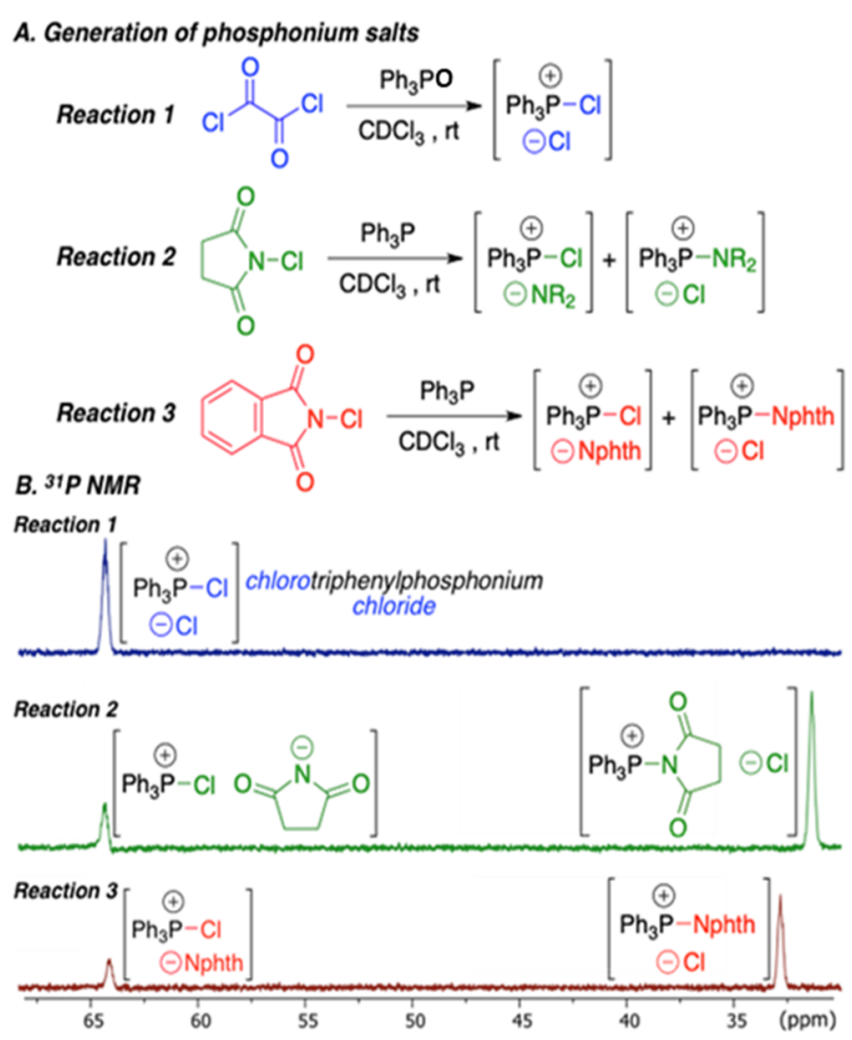

Figure 6. In situ generated phosphonium salts observed via ${ }^{31} \mathrm{P}$ NMR. Reaction 1 mixture consisted of triphenylphosphine oxide $\left(\mathrm{Ph}_{3} \mathrm{PO}\right)$ $\left(0.07 \mathrm{mmol}, 1\right.$ equiv) and oxalyl chloride $(\mathrm{COCl})_{2}(0.09 \mathrm{mmol}, 1.3$ equiv). Reaction 2 mixture consisted of triphenylphosphine $(0.08$ mmol, 1 equiv) and $N$-chlorosuccinimide ( $0.08 \mathrm{mmol}, 1$ equiv). Reaction 3 consisted of triphenylphosphine $\left(\mathrm{PPh}_{3}\right)(0.08 \mathrm{mmol}, 1$ equiv) and NCPhth (0.08 mmol, 1 equiv). All reaction mixtures were dissolved in $\mathrm{CDCl}_{3}$. at $32 \mathrm{ppm}$ corresponds to the imido-phosphonium salt. We confirmed this observation using high-resolution mass spectrometry (HR-MS). To the best of our knowledge, these imido-phosphonium salts had not been characterized before.

Following the identification and characterization of the phosphonium salts generated in situ, we attempted to observe other intermediates formed throughout the reaction. To do so, we added sodium benzoate to the previous $\mathrm{NCPhth} / \mathrm{PPh}_{3}$ mixture, and we observed a new peak at $23 \mathrm{ppm}$ by ${ }^{31} \mathrm{P} \mathrm{NMR}$ (Figure 7). We identified this new signal as being the (acyloxy)-phosphonium salt species for which a HR-MS was also obtained (see the Supporting Information).

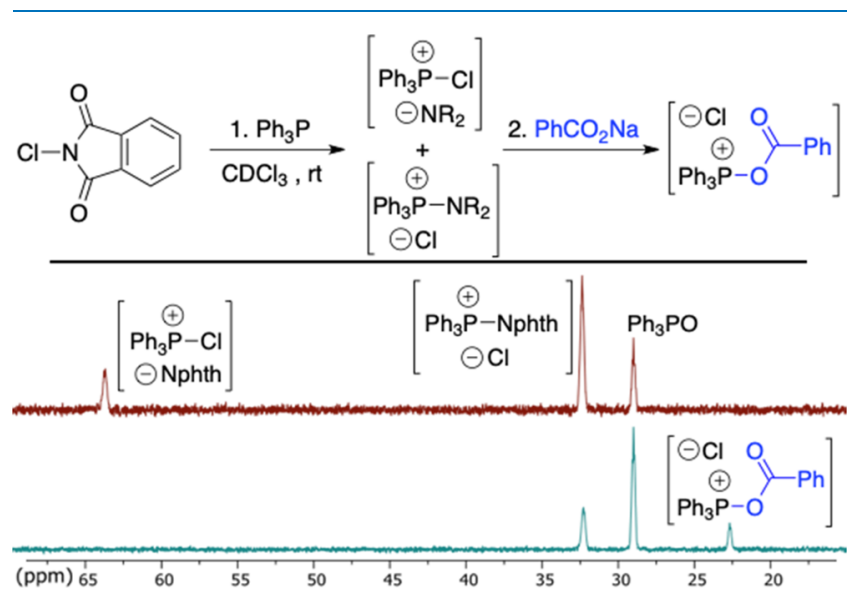

Figure 7. ${ }^{31} \mathrm{P}$ NMR (acyloxy)-phosphonium intermediate detection. Reaction mixture consisted of $\mathrm{PPh}_{3}$ (1 equiv), NCPhth (1 equiv), and $\mathrm{PhCOONa}$ (0.5 equiv), all solids dissolved in $\mathrm{CDCl}_{3}$.

Upon the formation of the (acyloxy)-phosphonium intermediate, we observed the complete consumption of the chloro-phosphonium salt at 64 ppm, while some imidophosphonium salts at $32 \mathrm{ppm}$ were still present. This observation highlights the difference in reactivity between these two species. More specifically, this suggests that the chloro-phosphonium species favorably reacts, kinetically, with the carboxylic acid. The imido-phosphonium intermediate may then serve as a precursor to the more reactive chlorophosphonium species; however, we cannot exclude the possibility that the imido-phosphonium intermediate also reacts with the carboxylic acid at a slower rate.

Another observation worth noting in Figure 6 is the relative ratio of chloro-phosphonium to imido-phosphonium salts across both $N$-haloimides in reactions 2 and 3 . When using NCS as the $N$-haloimide source, the ratio of chlorophosphonium to imido-phosphonium salts is 1:3 (Reaction 2, Figure 6), while it is 1:2 for $N$-chlorophthalimide (Reaction 3 , Figure 6). This difference in the formation of both species could be due to the difference in $\mathrm{p} K_{\mathrm{a}}$ between succinimide (9.5) and phthalimide (8.3). Given that the chlorophosphonium intermediate seems to react faster, we believe this could explain some of the different reactivity between our method and previously published ones, ${ }^{17 \mathrm{~d}}$ while providing future research on this topic is an avenue for further exploration and optimization.

Based on previous halophosphonium-mediated amidations ${ }^{16,17}$ and our experimental observations, we propose that the reaction begins with the in situ generation the chloro- and imido-phosphonium salts, 5 and $\mathbf{6}$, respectively (Figure 8). 


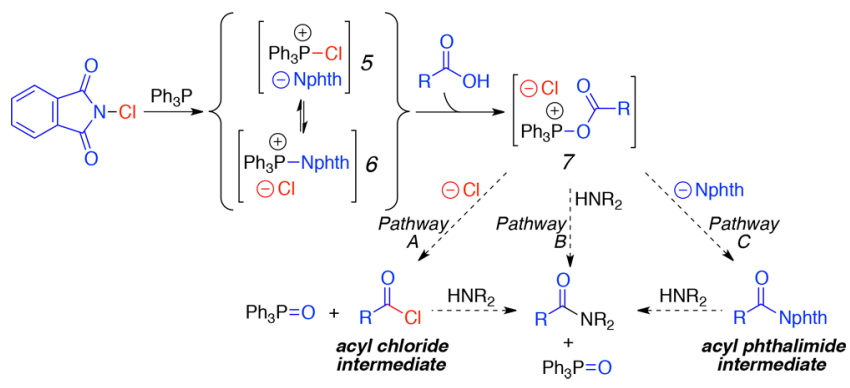

Figure 8. Proposed mechanism with different possible pathways.

These species then react with the carboxylic acids to generate the activated carboxylate 7 in the form of an (acyloxy)phosphonium salt. From intermediate 7, three possible pathways $(A, B$, and $C)$ can lead to the final amide products.

Transformation of (acyloxy)-phosphonium 7 into an acyl chloride via pathway $\boldsymbol{A}$ is analogous to previously proposed tranformations that use halophosphonium-mediated amidations. ${ }^{16 a, 17 b}$ Similarly, pathway $C$ involves the reaction of intermediate 7 with phthalimide to generate acyl phthalimide species, which we have shown can be generated efficiently if the amine coupling partner is replaced by a bulky base (compounds $\mathbf{4 a - 4 d}$, Figure 4). Finally, pathway $B$ is the direct transformation of the (acyloxy)-phosphonium 7 into the desired amide.

To determine which of these three possible pathways is most likely at play under our reaction conditions, we conducted a ${ }^{31} \mathrm{P}$ NMR study to quantify the rate of decomposition of the (acyloxy)-phosphonium intermediate 7 over time (Figure 9A).

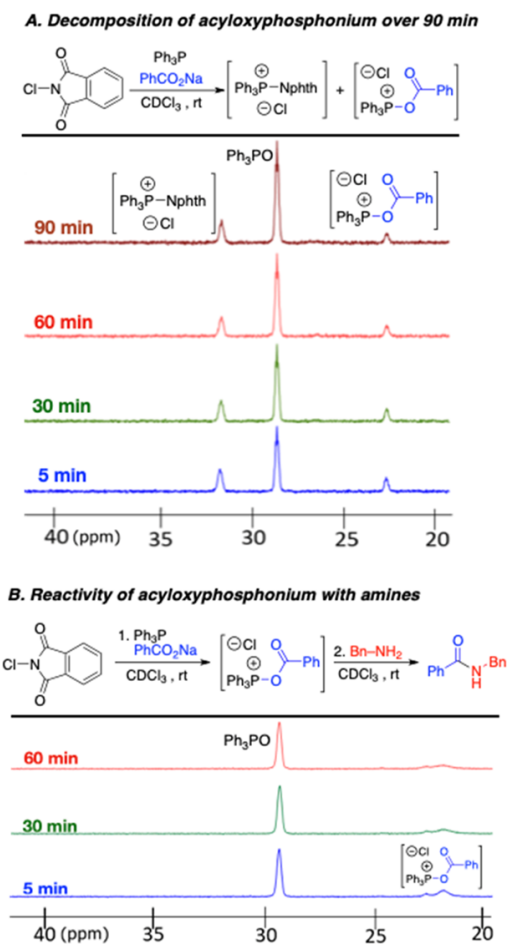

Figure 9. (A) ${ }^{31} \mathrm{P}$ NMR at different time frames of a reaction mixture containing $\mathrm{PPh}_{3}$ (1 equiv), NCPhth (1 equiv), and $\mathrm{PhCOONa}(0.5$ equiv) in $\mathrm{CDCl}_{3}$. (B) ${ }^{31} \mathrm{P} \mathrm{NMR}$ at different time frames of a reaction mixture containing $\mathrm{PPh}_{3}$ (1 equiv), NCPhth (1 equiv), benzylamine ( 1 equiv), and $\mathrm{PhCOONa}$ (0.5 equiv), in $\mathrm{CDCl}_{3}$.
We hypothesize that, if pathways $\boldsymbol{A}$ and $\boldsymbol{C}$ are main contributors for the formation of the final product, then intermediate 7 should decompose relatively quickly into the acyl chloride and the acylphthalimide in a nonreversible reaction that produces triphenylphosphine oxide, even when amine is not present. Indeed, intermediate 7 can react with the chloride or phthalimide anion present in the reaction as counter ions. As shown in Figure 9A, (acyloxy)-phosphonium species 7 does not seem to decompose significantly over the course of $90 \mathrm{~min}$, indicating that pathways $A$ and $C$ are unlikely to be major contributors under our reaction conditions. On the other hand, as shown in Figure 9B, the addition of benzylamine to the reaction leads to almost the instantaneous consumption of intermediate 7 and the consumption of the imido-phophonium salt $\mathbf{5}$.

To further discard pathway $C$ that involves the formation of the acyl phthalimides intermediate, which we were able to synthesize in Figure 4, we ran the control reaction presented in Figure 10A. When the acyl phthalimide is reacted with

A. Reaction between acyl phthalimides and primary amines ${ }^{24}$

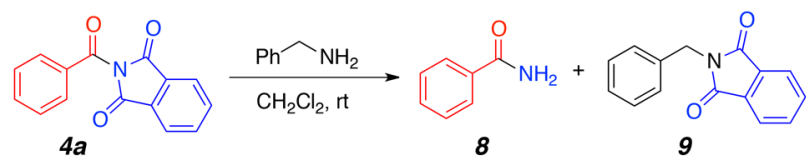

B. Radical trapping using TEMPO

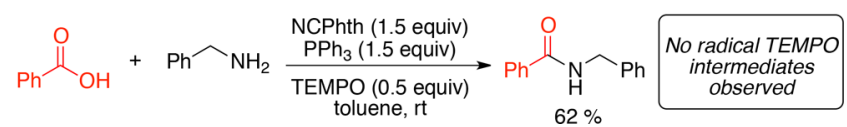

Figure 10. Acyl phthalimide and radical pathway investigations.

benzylamine, it does not produce the corresponding $\mathrm{N}$ benzylbenzamide. Instead, it generates the primary benzamide 8 and phthalimide-protected benzylamine 9 via a phthalimide transfer pathway. This observation is also supported by literature precedent showing that when introduced to amine nucleophiles acyl phthalimides cleave to provide the phthalimide-protected amine and primary benzamide derivative. $^{24}$ Therefore, this observation further supports that an acyl phthalimide intermediate following pathway $\boldsymbol{C}$ is unlikely. Lastly, we conducted a TEMPO radical trapping experiment to discard any possible radical pathways (Figure 10B). Indeed, when TEMPO was added to our reaction mixture, the desired amide product was still generated albeit in slightly eroded yields.

Based on the results above, we propose that the reaction begins with the in-situ generation of the chloro- and imidophosphonium salts, 5 and 6 , respectively (Figure 11). These

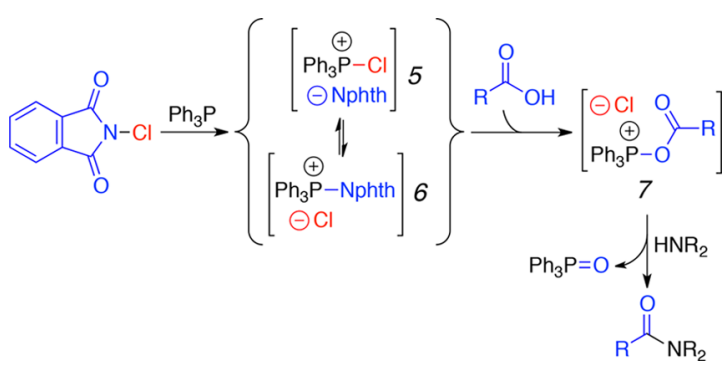

Figure 11. Proposed mechanism and its confirmed intermediates. 
species then react with the carboxylic acids to generate the activated carboxylate 7 in the form of an acyloxy-phosphonium salt. Importantly, our NMR experiments indicate that salt 5 is more reactive than 6 in the presence of a carboxylate (Figure 7). Then, the (acyloxy)-phosphonium species 7 undergoes direct amidation generating the desired product and forming triphenylphosphine oxide as a byproduct (Figure 11).

\section{CONCLUSIONS}

In summary, we have developed a mild methodology for the amidation of carboxylic acids with both $\mathrm{I}^{\circ}$ and $\mathrm{II}^{\circ}$ amines. This work uses triphenylphosphine and $\mathrm{N}$-chlorophthalimide as bench-stable reagents to generate in situ reactive phosphonium species that efficiently activate carboxylic acids. Our mechanistic work employed ${ }^{31} \mathrm{P}$ NMR and HR-MS techniques to observe and characterize the different intermediates generated throughout the reaction. Our work is the first to characterize imido-phosphonium intermediates and observe its reactivity differences with chloro-phosphonium species. These observations can help the continual improvement of phosphoniumbased transformations and characterize the species involved. Future work in our lab aims at employing similar strategies to enable other deoxyamination transformations.

\section{EXPERIMENTAL SECTION}

General Considerations. All reagents were purchased and used without further purification unless otherwise noted. All reactions were performed under an inert atmosphere unless otherwise stated. Room temperature refers to $24{ }^{\circ} \mathrm{C}$. Solvents were freshly distilled under anhydrous conditions before use.

Moisture-sensitive reactions were performed using flamedried glassware under an atmosphere of dry argon (Ar).

Flame-dried equipment was stored in a $130{ }^{\circ} \mathrm{C}$ oven before use and either allowed to cool in a cabinet desiccator or assembled hot and allowed to cool under an inert atmosphere. Air- and moisture-sensitive liquids and solutions were transferred via a plastic or glass syringe.

Chromatographic purification of products was accomplished using a flash column chromatography Silicycle Silica flash F60 (particle size: $40-63 \mu \mathrm{m}, 230-400 \mathrm{mesh}$ ).

Thin-layer chromatography was performed on EMD Millipore silica gel $60 \mathrm{~F}_{254}$ glass-backed plates (layer thickness: $250 \mu \mathrm{m}$, particle size: 10-12 $\mu \mathrm{m}$, impregnated with a fluorescent indicator). Visualization of the developed chromatogram was accomplished by fluorescence quenching under shortwave UV light and/or by staining with phosphomolybdic acid, $p$-anisaldehyde, or $\mathrm{KMnO}_{4}$ stain.

Instrumentation. NMR spectrometry: NMR spectra were obtained on Bruker spectrometers operating at 400 or 500 $\mathrm{MHz}$ for ${ }^{1} \mathrm{H}$ NMR and 101 or $126 \mathrm{MHz}$ for ${ }^{13} \mathrm{C}\left\{{ }^{1} \mathrm{H}\right\}$ NMR. Chemical shifts $(\delta \mathrm{ppm})$, multiplicity $(\mathrm{s}=$ singlet, $\mathrm{d}=$ doublet, $\mathrm{dd}=$ doublet of doublets, $\mathrm{t}=$ triplet, $\mathrm{q}=$ quartet, and $\mathrm{m}=$ multiplet), coupling constant $(\mathrm{Hz})$, and the relative integral was made in reference to NMR solvent signals.

Mass spectrometry: gas chromatograph-mass spectrometry were obtained using a Hewlett Packard GC system HP 6890 Series coupled with a HP 5973 mass-selective detector. Highresolution mass spectra were obtained using an Agilent Technologies 6520 Accurate-Mass Q-TOF LC/MS with electrospray ionization (ESI).

General Method A: Amide Synthesis. A flame-dried $10 \mathrm{~mL}$ microwave vial was charged with $N$-chlorophthalimide (1.5 equiv), triphenylphosphine (1.5 equiv), and the desired carboxylic acid (100 mg, 1 equiv) under an argon atmosphere. A solvent ( $3 \mathrm{~mL}$ of toluene or acetonitrile) was then added, and the resulting solution was stirred for $1 \mathrm{~min}$ before adding the desired amine reagent ( 3 equiv). The resulting mixture was stirred at room temperature for $12 \mathrm{~h}$ in an inert atmosphere. The crude reaction was then dissolved in $10 \mathrm{~mL}$ of ethyl acetate, and the solution was washed using a saturated solution of sodium bicarbonate $(8 \mathrm{~mL})$ and a brine solution $(8 \mathrm{~mL})$. The organic layer was dried with sodium sulfate and then concentrated via rotatory evaporation. The corresponding amide was isolated via column chromatography.

General Method B: Acyl Phthalimide Synthesis. A flamedried $10 \mathrm{~mL}$ microwave vial was charged with $N$-chlorophthalimide (1.5 equiv), triphenylphosphine (1.5 equiv), DMAP ( 1.5 equiv), and the desired carboxylic acid (100 mg, 1 equiv) under an argon atmosphere. Toluene $(3 \mathrm{~mL})$ was then added, and the resulting solution was stirred for $12 \mathrm{~h}$ at $80^{\circ} \mathrm{C}$ in an inert atmosphere. The crude reaction was then dissolved in 10 $\mathrm{mL}$ of ethyl acetate, and the solution was washed using a saturated solution of sodium bicarbonate $(8 \mathrm{~mL})$ and a brine solution $(8 \mathrm{~mL})$. The organic layer was dried with sodium sulfate and then concentrated via rotatory evaporation. The corresponding acyl phthalimide was isolated via column chromatography.

Compounds Synthesis and Characterization. Preparation of N-Benzylbenzamide (3aa). Using general method A (100 mg of benzoic acid, $322 \mathrm{mg}$ of triphenylphosphine, 223 mg of $N$-chlorophthalimide, $263 \mathrm{mg}$ of benzylamine, and $3 \mathrm{~mL}$ of toluene), the product was purified by column chromatography $\left(R_{f}=0.53, \mathrm{DCM} /\right.$ hexane $/$ EtOAc $\left.=5: 3: 1\right)$ and isolated in $83 \%$ yield, $140 \mathrm{mg}$. Spectra data matched reported data. ${ }^{25}$ ${ }^{1} \mathrm{H}$ NMR $\left(400 \mathrm{MHz}, \mathrm{CDCl}_{3}\right) \delta 7.83-7.60(\mathrm{~m}, 2 \mathrm{H}), 7.44-7.35$ (m, 1H), 7.36-7.25 (m, 2H), $7.25(\mathrm{~m}, 4 \mathrm{H}), 6.51(\mathrm{~s}, 1 \mathrm{H}), 4.53$ $(\mathrm{d}, J=5.7 \mathrm{~Hz}, 2 \mathrm{H}) \cdot{ }^{13} \mathrm{C}\left\{{ }^{1} \mathrm{H}\right\}$ NMR $\left(100 \mathrm{MHz}, \mathrm{CDCl}_{3}\right) \delta$ $167.4,138.3,134.5,131.5,128.8,128.6,127.9,127.6,127$, 44.1.

Preparation of N-Benzyl-N-methylbenzamide (3ab). Using general method A (100 mg of benzoic acid, $322 \mathrm{mg}$ of triphenylphosphine, $223 \mathrm{mg}$ of $\mathrm{N}$-chlorophthalimide, 199 mg of $N$-benzylmethylamine, and $3 \mathrm{~mL}$ of $\mathrm{MeCN}$ ), the product was purified by column chromatography $\left(R_{f}=0.62\right.$, $\mathrm{DCM} /$ hexane $/ \mathrm{EtOAc}=5: 3: 1)$ and isolated in $65 \%$ yield, 120 mg. Spectra data matched reported data. ${ }^{26}{ }^{1} \mathrm{H}$ NMR (400 $\mathrm{MHz}, \mathrm{CDCl}_{3}$ ) $\delta 7.41-7.08(\mathrm{~m}, 10 \mathrm{H}), 4.49$ (d, 2H), 2.79 (d, J $=72.1 \mathrm{~Hz}, 3 \mathrm{H}) \cdot{ }^{13} \mathrm{C}\left\{{ }^{1} \mathrm{H}\right\} \operatorname{NMR}\left(100 \mathrm{MHz}, \mathrm{CDCl}_{3}\right) \delta 169$, $136.3,129.6,128.8,128.5,127.6,127,126.9,55.2,50.9,37$, 33.2.

Preparation of N-Cyclohexylbenzamide (3ac). Using general method A, (100 mg of benzoic acid, $322 \mathrm{mg}$ of triphenylphosphine, $223 \mathrm{mg}$ of $\mathrm{N}$-chlorophthalimide, $244 \mathrm{mg}$ of cyclohexylamine, and $3 \mathrm{~mL}$ of toluene), the product was purified by column chromatography $\left(R_{f}=0.59, \mathrm{DCM} /\right.$ hexane/ EtOAc $=5: 3: 1)$ and isolated in $76 \%$ yield, $130 \mathrm{mg}$. Spectra data matched reported data. ${ }^{27}$

${ }^{1} \mathrm{H}$ NMR (400 MHz, $\mathrm{CDCl}_{3}$ ) $\delta 7.82-7.74(\mathrm{~m}, 2 \mathrm{H}), 7.53-$ $7.45(\mathrm{~m}, 1 \mathrm{H}), 7.44-7.38(\mathrm{~m}, 2 \mathrm{H}), 6.14(\mathrm{~s}, 1 \mathrm{H}), 3.99(\mathrm{~m}, 1 \mathrm{H})$, $2.03(\mathrm{~m}, 2 \mathrm{H}), 1.81-1.70(\mathrm{~m}, 2 \mathrm{H}), 1.70-1.61(\mathrm{~m}, 1 \mathrm{H}), 1.48-$ $1.35(\mathrm{~m}, 2 \mathrm{H}), 1.32-1.13(\mathrm{~m}, 3 \mathrm{H})$.

${ }^{13} \mathrm{C}\{1 \mathrm{H}\} \mathrm{NMR}\left(100 \mathrm{MHz}, \mathrm{CDCl}_{3}\right) \delta 166.5,135.2,131.2$, 128.5, 126.9, 48.7, 33.2, 25.6, 25.

Preparation of (S)-N-(1-Phenylethyl)benzamide (3ad). Using general method A (100 mg of benzoic acid, $322 \mathrm{mg}$ 
of triphenylphosphine, $223 \mathrm{mg}$ of $\mathrm{N}$-chlorophthalimide, 298 $\mathrm{mg}$ of $(S)-(-)$-1-phenylethylamine, and $3 \mathrm{~mL}$ of toluene), the product was purified by column chromatography $\left(R_{f}=0.63\right.$, $\mathrm{DCM} /$ hexane/EtOAc $=5: 3: 1)$ and isolated in $72 \%$ yield, 150 mg. Spectra data matched reported data. ${ }^{28}$

${ }^{1} \mathrm{H}$ NMR (400 MHz, $\mathrm{CDCl}_{3}$ ) $\delta 7.71-7.66(\mathrm{~m}, 2 \mathrm{H}), 7.43-$ $7.37(\mathrm{~m}, 1 \mathrm{H}), 7.35-7.25(\mathrm{~m}, 6 \mathrm{H}), 7.21-7.17(\mathrm{~m}, 1 \mathrm{H}), 6.36$ (s, 1H), 5.25 (p, $J=7.1 \mathrm{~Hz}, 1 \mathrm{H}), 1.52(\mathrm{~d}, J=7.0 \mathrm{~Hz}, 3 \mathrm{H})$.

${ }^{13} \mathrm{C}\{1 \mathrm{H}\}$ NMR $\left(100 \mathrm{MHz}, \mathrm{CDCl}_{3}\right) \delta 166.9,143.2,134.7$, 131.4, 128.8, 128.6, 127.5, 127, 126.3, 49.2, 21.8 .

Preparation of $\mathrm{N}$-(2-Phenylpropan-2-yl)benzamide (3ae). Using general method A (100 mg of benzoic acid, $322 \mathrm{mg}$ of triphenylphosphine, $223 \mathrm{mg}$ of $\mathrm{N}$-chlorophthalimide, $332 \mathrm{mg}$ of cumylamine, and $3 \mathrm{~mL}$ of toluene), the product was purified by column chromatography $\left(R_{f}=0.67, \mathrm{DCM} /\right.$ hexane $/$ EtOAc $=5: 3: 1)$ and isolated in $51 \%$ yield, $100 \mathrm{mg}$. Spectra data matched reported data. ${ }^{29}$

${ }^{1} \mathrm{H}$ NMR (400 MHz, $\left.\mathrm{CDCl}_{3}\right) \delta 7.83-7.76(\mathrm{~m}, 2 \mathrm{H}), 7.56-$ $7.46(\mathrm{~m}, 3 \mathrm{H}), 7.50-7.40(\mathrm{~m}, 2 \mathrm{H}), 7.38(\mathrm{t}, J=8.6,7.6,7.0 \mathrm{~Hz}$, $2 \mathrm{H}), 7.30-7.25(\mathrm{~m}, 1 \mathrm{H})$.

${ }^{13} \mathrm{C}\{1 \mathrm{H}\} \mathrm{NMR}\left(100 \mathrm{MHz}, \mathrm{CDCl}_{3}\right) \delta 166,146.9,135.5$, $131.3,128.6,128.5,126.9,126.8,124.8,56.3,29.2$.

Preparation of (Z)-N-(Octadec-9-en-1-yl)benzamide (3af). Using general method A (100 mg of benzoic acid, $322 \mathrm{mg}$ of triphenylphosphine, $223 \mathrm{mg}$ of $\mathrm{N}$-chlorophthalimide, $657 \mathrm{mg}$ of oleylamine, and $3 \mathrm{~mL}$ of toluene), the product was purified by column chromatography $\left(R_{f}=0.76, \mathrm{DCM} /\right.$ hexane $/$ EtOAc $=5: 3: 1)$ and isolated in $40 \%$ yield, $122 \mathrm{mg}$. Spectra data matched reported data. ${ }^{30}$

${ }^{1} \mathrm{H}$ NMR (400 MHz, $\left.\mathrm{CDCl}_{3}\right) \delta 7.78(\mathrm{dd}, J=7.0,1.8 \mathrm{~Hz}$, $2 \mathrm{H}), 7.51-7.39(\mathrm{~m}, 3 \mathrm{H}), 6.36(\mathrm{~s}, 1 \mathrm{H}), 5.44-5.32(\mathrm{~m}, 2 \mathrm{H})$, $3.44(\mathrm{~m}, 3 \mathrm{H}), 2.17-1.90(\mathrm{~m}, 4 \mathrm{H}), 1.62(\mathrm{p}, J=7.1 \mathrm{~Hz}, 2 \mathrm{H})$, $1.43-1.21(\mathrm{~m}, 22 \mathrm{H}), 0.87(\mathrm{~s}, 3 \mathrm{H})$.

${ }^{13} \mathrm{C}\{1 \mathrm{H}\} \mathrm{NMR}\left(100 \mathrm{MHz}, \mathrm{CDCl}_{3}\right) \delta 167.5,135,134.5$, $131.2,130.6,129.8,128.9,128.5,126.9,40.1,31.9,29.8,29.7$, 29.5, 27.2, 22.7, 14.1 .

Preparation of tert-Butyl Benzoylglycinate (3ag). Using general method A (100 mg of benzoic acid, $322 \mathrm{mg}$ of triphenylphosphine, $223 \mathrm{mg}$ of $\mathrm{N}$-chlorophthalimide, $323 \mathrm{mg}$ of tert-butyl, 2-aminoacetate, and $3 \mathrm{~mL}$ of toluene), the product was purified by column chromatography $\left(R_{f}=0.49\right.$, $\mathrm{DCM} /$ hexane/EtOAc $=5: 3: 1)$ and isolated in $54 \%$ yield, 100 mg. Spectra data matched reported data. ${ }^{31}$

${ }^{1} \mathrm{H}$ NMR (400 MHz, $\mathrm{CDCl}_{3}$ ) $\delta 7.87-7.79(\mathrm{~m}, 2 \mathrm{H}), 7.56-$ $7.48(\mathrm{~m}, 1 \mathrm{H}), 7.48-7.40(\mathrm{~m}, 2 \mathrm{H}), 6.71(\mathrm{~s}, 1 \mathrm{H}), 4.15(\mathrm{~d}, J=$ $4.9 \mathrm{~Hz}, 2 \mathrm{H}), 1.52(\mathrm{~s}, 9 \mathrm{H})$.

${ }^{13} \mathrm{C}\{1 \mathrm{H}\} \mathrm{NMR}\left(100 \mathrm{MHz}, \mathrm{CDCl}_{3}\right) \delta 169.4,167.2,134$, 131.7, 128.6, 127, 82.5, 42.5, 28.1.

Preparation of $\mathrm{N}$-Phenylbenzamide (3ah). Using general method A (100 mg of benzoic acid, $322 \mathrm{mg}$ of triphenylphosphine, $223 \mathrm{mg}$ of $\mathrm{N}$-chlorophthalimide, $229 \mathrm{mg}$ of aniline, and $3 \mathrm{~mL}$ of toluene), the product was purified by column chromatography $\left(R_{f}=0.84, \mathrm{DCM} /\right.$ hexane $/$ EtOAc $=$ $5: 3: 1)$ and isolated in $69 \%$ yield, $111 \mathrm{mg}$. Spectra data matched reported data. $^{32}$

${ }^{1} \mathrm{H}$ NMR (400 MHz, $\left.\mathrm{CDCl}_{3}\right) \delta 7.92-7.83(\mathrm{~m}, 3 \mathrm{H}), 7.70-$ $7.61(\mathrm{~m}, 2 \mathrm{H}), 7.59-7.51(\mathrm{~m}, 1 \mathrm{H}), 7.51-7.43(\mathrm{~m}, 2 \mathrm{H}), 7.41-$ $7.32(\mathrm{~m}, 2 \mathrm{H}), 7.20-7.11(\mathrm{~m}, 1 \mathrm{H})$.

${ }^{13} \mathrm{C}\{1 \mathrm{H}\} \mathrm{NMR}\left(100 \mathrm{MHz}, \mathrm{CDCl}_{3}\right) \delta 165.8,138,135.1$, 131.9, 129.1, 128.8, 127, 124.6, 120.3 .

Preparation of $\mathrm{N}$-Mesitylbenzamide (3ai). Using general method A (100 mg of benzoic acid, $322 \mathrm{mg}$ of triphenylphosphine, $223 \mathrm{mg}$ of $\mathrm{N}$-chlorophthalimide, $332 \mathrm{mg}$ of 2,4,6-trimethylaniline, and $3 \mathrm{~mL}$ of toluene), the product was purified by column chromatography $\left(R_{f}=0.28,100 \%\right.$ DCM) and isolated in $56 \%$ yield, $110 \mathrm{mg}$. Spectra data matched reported data. ${ }^{33}$

${ }^{1} \mathrm{H}$ NMR (400 MHz, $\left.\mathrm{CDCl}_{3}\right) \delta 7.92-7.76(\mathrm{~m}, 2 \mathrm{H}), 7.55-$ $7.45(\mathrm{~m}, 1 \mathrm{H}), 7.40(\mathrm{dd}, J=7.5,1.3 \mathrm{~Hz}, 2 \mathrm{H}), 7.33(\mathrm{~d}, 1 \mathrm{H})$, $6.84(\mathrm{~s}, 2 \mathrm{H}), 2.22(\mathrm{~s}, 3 \mathrm{H}), 2.15(\mathrm{~s}, 6 \mathrm{H})$.

${ }^{13} \mathrm{C}\{1 \mathrm{H}\} \mathrm{NMR}\left(100 \mathrm{MHz}, \mathrm{CDCl}_{3}\right) \delta 166.3,137.1,135.3$, 134.7, 131.7, 131.3, 129, 128.7, 127.2, 21, 18.4.

Preparation of N-(2,6-Diisopropylphenyl)benzamide (3aj). Using general method A (100 mg of benzoic acid, 322 $\mathrm{mg}$ of triphenylphosphine, $223 \mathrm{mg}$ of $\mathrm{N}$-chlorophthalimide, $435 \mathrm{mg}$ of 2,6-diisopropylaniline, and $3 \mathrm{~mL}$ of toluene), the product was purified by column chromatography $\left(R_{f}=0.39\right.$, $100 \% \mathrm{DCM}$ ) and isolated in $49 \%$ yield, $113 \mathrm{mg}$. Spectra data matched reported data. ${ }^{34}$

${ }^{1} \mathrm{H}$ NMR (400 MHz, $\mathrm{CDCl}_{3}$ ) $\delta 7.87-7.79(\mathrm{~m}, 2 \mathrm{H}), 7.52-$ $7.46(\mathrm{~m}, 1 \mathrm{H}), 7.44-7.38(\mathrm{~m}, 2 \mathrm{H}), 7.33-7.24(\mathrm{~m}, 2 \mathrm{H}), 7.16(\mathrm{t}$, $J=8.3 \mathrm{~Hz}, 2 \mathrm{H}$ ), 3.07 (hept, $J=6.8 \mathrm{~Hz}, 2 \mathrm{H}), 1.14$ (d, $J=6.9$ $\mathrm{Hz}, 12 \mathrm{H})$.

${ }^{13} \mathrm{C}\{1 \mathrm{H}\} \mathrm{NMR}\left(100 \mathrm{MHz}, \mathrm{CDCl}_{3}\right) \delta 166.9,146.5,134.7$, $131.8,131.2,128.9,128.5,127.2,28.9,23.7$.

Preparation of N,N-Diphenylbenzamide (3ak). Using general method B (100 mg of benzoic acid, $322 \mathrm{mg}$ of triphenylphosphine, $223 \mathrm{mg}$ of $\mathrm{N}$-chlorophthalimide, $277 \mathrm{mg}$ of diphenylamine, and $3 \mathrm{~mL}$ of $\mathrm{MeCN}$ ), the product was purified by column chromatography $\left(R_{f}=0.55\right.$, hexane/EtOAc $=2: 1)$ and isolated in $55 \%$ yield, $123 \mathrm{mg}$. Spectra data matched reported data. ${ }^{35}$

${ }^{1} \mathrm{H}$ NMR (400 MHz, $\left.\mathrm{CDCl}_{3}\right) \delta 7.41-7.36$ (m, 2H), 7.24$7.17(\mathrm{~m}, 5 \mathrm{H}), 7.15-7.04(\mathrm{~m}, 8 \mathrm{H})$.

${ }^{13} \mathrm{C}\{1 \mathrm{H}\} \mathrm{NMR}\left(100 \mathrm{MHz}, \mathrm{CDCl}_{3}\right) \delta 170.2,144,136.2$, 130.2, 129.2, 129.1, 127.9, 127.5, 126.4 .

Preparation of N-Methyl-N-phenylbenzamide (3al). Using general method B ( $100 \mathrm{mg}$ of benzoic acid, $322 \mathrm{mg}$ of triphenylphosphine, $223 \mathrm{mg}$ of $\mathrm{N}$-chlorophthalimide, $176 \mathrm{mg}$ of $\mathrm{N}$-methylaniline, and $3 \mathrm{~mL}$ of $\mathrm{MeCN}$ ), the product was purified by column chromatography $\left(R_{f}=0.47, \mathrm{DCM} /\right.$ hexane/ EtOAc $=5: 3: 1)$ and isolated in 65\% yield, $112 \mathrm{mg}$. Spectra data matched reported data. ${ }^{36}$

${ }^{1} \mathrm{H}$ NMR (400 MHz, $\mathrm{CDCl}_{3}$ ) $\delta 7.35-7.27$ (m, 2H), 7.26$7.18(\mathrm{~m}, 3 \mathrm{H}), 7.14(\mathrm{~m}, 3 \mathrm{H}), 7.09-6.97$ (m, 2H), 3.54-3.47 $(\mathrm{m}, 3 \mathrm{H})$.

${ }^{13} \mathrm{C}\{1 \mathrm{H}\} \mathrm{NMR}\left(100 \mathrm{MHz}, \mathrm{CDCl}_{3}\right) \delta 170.2,144.9,136$, 129.6, 129.2, 128.7, 127.3, 126.9, 126.5, 38.4.

Preparation of Phenyl(pyrrolidin-1-yl)methanone (3am). Using general method B (100 mg of benzoic acid, $322 \mathrm{mg}$ of triphenylphosphine, $223 \mathrm{mg}$ of $N$-chlorophthalimide, $117 \mathrm{mg}$ of pyrrolidine, and $3 \mathrm{~mL}$ of $\mathrm{MeCN}$ ), the product was purified by column chromatography $\left(R_{f}=0.29, \mathrm{DCM} /\right.$ hexane/EtOAc $=5: 2: 3)$ and isolated in $71 \%$ yield, $102 \mathrm{mg}$. Spectra data matched reported data. ${ }^{37}$

${ }^{1} \mathrm{H}$ NMR (400 MHz, $\left.\mathrm{CDCl}_{3}\right) \delta 7.42(\mathrm{~m}, 2 \mathrm{H}), 7.30(\mathrm{~m}, 3 \mathrm{H})$, $3.62-3.20(\mathrm{~m}, 3 \mathrm{H}), 1.94-1.72(\mathrm{~m}, 4 \mathrm{H})$.

${ }^{13} \mathrm{C}\{1 \mathrm{H}\}$ NMR $\left(100 \mathrm{MHz}, \mathrm{CDCl}_{3}\right) \delta 169.7,137.3,133$, 129.7, 128.2, 127.1, 49.5, 46.1, 26.4, 24.4.

Preparation of Phenyl(piperidin-1-yl)methanone (3an). Using general method B (100 mg of benzoic acid, $322 \mathrm{mg}$ of triphenylphosphine, $223 \mathrm{mg}$ of $N$-chlorophthalimide, $139 \mathrm{mg}$ of piperidine, and $3 \mathrm{~mL}$ of $\mathrm{MeCN}$ ), the product was purified by column chromatography $\left(R_{f}=0.60,100 \%\right.$ EtOAc $)$ and isolated in $45 \%$ yield, $70 \mathrm{mg}$. Spectra data matched reported data. $^{38}$ 
${ }^{1} \mathrm{H}$ NMR (400 MHz, $\left.\mathrm{CDCl}_{3}\right) \delta 7.28(\mathrm{~s}, 5 \mathrm{H}), 3.42(\mathrm{~d}, J=$ $148.3 \mathrm{~Hz}, 4 \mathrm{H}), 1.79-1.09(\mathrm{~m}, 5 \mathrm{H})$.

${ }^{13} \mathrm{C}\{1 \mathrm{H}\} \mathrm{NMR}\left(100 \mathrm{MHz}, \mathrm{CDCl}_{3}\right) \delta 170,136.5,129.2$, 128.3, 126.7, 48.7, 43.1, 26.4, 25.7, 24.5.

Preparation of Morpholino(phenyl)methanone (3ao). Using general method B (100 mg of benzoic acid, $322 \mathrm{mg}$ of triphenylphosphine, $223 \mathrm{mg}$ of $\mathrm{N}$-chlorophthalimide, $143 \mathrm{mg}$ of morpholine, and $3 \mathrm{~mL}$ of $\mathrm{MeCN}$ ), the product was purified by column chromatography $\left(R_{f}=0.33\right.$, petroleum ether/ EtOAc $=1: 1)$ at $41 \%$ yield, $64 \mathrm{mg}$. Spectra data matched reported data. ${ }^{39}$

${ }^{1} \mathrm{H}$ NMR (400 MHz, $\left.\mathrm{CDCl}_{3}\right) \delta 7.31(\mathrm{~m}, 5 \mathrm{H}), 3.47(\mathrm{~m}, 8 \mathrm{H})$.

${ }^{13} \mathrm{C}\{1 \mathrm{H}\} \mathrm{NMR}\left(100 \mathrm{MHz}, \mathrm{CDCl}_{3}\right) \delta 170.3,135.3,132$, 131.9, 129.8, 128.5, 128.4, 127.4, 66.7, 48.1, 42.6.

Preparation of N-Benzyl-4-methoxybenzamide (3ba). Using general method A (100 mg of 4-methoxy-benzoic acid, $259 \mathrm{mg}$ of triphenylphosphine, $179 \mathrm{mg}$ of $\mathrm{N}$-chlorophthalimide, $211 \mathrm{mg}$ of benzylamine, and $3 \mathrm{~mL}$ of toluene), the product was purified by column chromatography $\left(R_{f}=0.14\right.$, hexane $/$ EtOAc $=3: 1$ ) and isolated in $84 \%$ yield, $166 \mathrm{mg}$. Spectra data matched reported data. ${ }^{41}$

${ }^{1} \mathrm{H}$ NMR (400 MHz, $\left.\mathrm{CDCl}_{3}\right) \delta 7.68(\mathrm{~d}, J=8.8 \mathrm{~Hz}, 2 \mathrm{H})$, $7.29-7.11(\mathrm{~m}, 4 \mathrm{H}), 6.82(\mathrm{~d}, J=8.9 \mathrm{~Hz}, 2 \mathrm{H}), 6.82(\mathrm{~d}, J=8.9$ $\mathrm{Hz}, 2 \mathrm{H}), 6.40(\mathrm{~s}, 1 \mathrm{H}), 3.75(\mathrm{~s}, 3 \mathrm{H})$.

${ }^{13} \mathrm{C}\{1 \mathrm{H}\}$ NMR $\left(100 \mathrm{MHz}, \mathrm{CDCl}_{3}\right) \delta 166.8,162.3,138.6$, 128.8, 128.7, 127.9, 127.5, 126.7, 113.8, 55.4, 44.1.

Preparation of N-Benzyl-4-methoxy- $\mathrm{N}$-methylbenzamide (3bb). Using general method A, (100 mg of 4-methoxybenzoic acid, $259 \mathrm{mg}$ of triphenylphosphine, $179 \mathrm{mg}$ of $\mathrm{N}$ chlorophthalimide, $160 \mathrm{mg}$ of $\mathrm{N}$-benzylmethylamine, and $3 \mathrm{~mL}$ of $\mathrm{MeCN}$ ), the product was purified by column chromatography $\left(R_{f}=0.40\right.$, hexane $/$ EtOAc $\left.=1: 1\right)$ and isolated in $87 \%$ yield, $182 \mathrm{mg}$. Spectra data matched reported data. ${ }^{40}$

${ }^{1} \mathrm{H}$ NMR (400 MHz, $\mathrm{CDCl}_{3}$ ) $\delta 7.47-7.39$ (m, 2H), 7.39$7.33(\mathrm{~m}, 2 \mathrm{H}), 7.32-7.23(\mathrm{~m}, 2 \mathrm{H}), 6.89$ (d, $J=8.2 \mathrm{~Hz}, 2 \mathrm{H})$, 4.65 (s, 2H), $3.81(\mathrm{~s}, 3 \mathrm{H}), 2.95(\mathrm{~s}, 3 \mathrm{H})$.

${ }^{13} \mathrm{C}\{1 \mathrm{H}\} \mathrm{NMR}\left(100 \mathrm{MHz}, \mathrm{CDCl}_{3}\right) \delta 160.8,137.1,129,128$, 127, 113.7, 55.3.

Preparation of N-Benzyl-4-iodobenzamide (3ca). Using general method A (100 mg of 4-iodo-benzoic acid, $159 \mathrm{mg}$ of triphenylphosphine, $110 \mathrm{mg}$ of $\mathrm{N}$-chlorophthalimide, $121 \mathrm{mg}$ of benzylamine, and $3 \mathrm{~mL}$ of toluene), the product was purified by column chromatography $\left(R_{f}=0.52, \mathrm{EtOAc} /\right.$ hexane $/ \mathrm{DCM}$ $=1: 2.5: 1)$ and isolated in $73 \%$ yield, $100 \mathrm{mg}$. Spectra data matched reported data. ${ }^{9 a}$

${ }^{1} \mathrm{H}$ NMR (400 MHz, $\left.\mathrm{CDCl}_{3}\right) \delta 7.83-7.76(\mathrm{~m}, 2 \mathrm{H}), 7.56-$ $7.50(\mathrm{~m}, 2 \mathrm{H}), 7.41-7.33(\mathrm{~m}, 5 \mathrm{H}), 6.40(\mathrm{~s}, 1 \mathrm{H}), 4.65$ (d, $J=$ $5.6 \mathrm{~Hz}, 2 \mathrm{H})$.

${ }^{13} \mathrm{C}$ NMR $\left(100 \mathrm{MHz}, \mathrm{CDCl}_{3}\right) \delta 166.5,138,137.9,137.8$, $133.8,128.9,128.6,128,127.8,98.5,44.3$.

Preparation of $\mathrm{N}$-Benzyl-4-iodo- $\mathrm{N}$-methylbenzamide (3c̀b). Using general method A (100 mg of 4-iodo-benzoic acid, $159 \mathrm{mg}$ of triphenylphosphine, $110 \mathrm{mg}$ of $\mathrm{N}$ chlorophthalimide, $98 \mathrm{mg}$ of $\mathrm{N}$-benzylmethylamine, and 3 $\mathrm{mL}$ of $\mathrm{MeCN}$ ), the product was purified by column chromatography $\left(R_{f}=0.48, \mathrm{DCM} /\right.$ hexane $/$ EtOAc $\left.=1: 2.5: 1\right)$ and isolated in $87 \%$ yield, $123 \mathrm{mg}$. Spectra data matched reported data. $^{41}$

${ }^{1} \mathrm{H}$ NMR (400 MHz, $\left.\mathrm{CDCl}_{3}\right) \delta 7.73(\mathrm{~s}, 2 \mathrm{H}), 7.45-7.07(\mathrm{~m}$, $7 \mathrm{H}), 4.61(\mathrm{~d}, J=96.0 \mathrm{~Hz}, 2 \mathrm{H}), 2.93(\mathrm{~d}, J=67.1 \mathrm{~Hz}, 3 \mathrm{H})$.

${ }^{13} \mathrm{C}\{1 \mathrm{H}\} \mathrm{NMR}\left(100 \mathrm{MHz}, \mathrm{CDCl}_{3}\right) \delta 137.6,128.8,127.7$, $95.8,55.2,51,37,33.4$.
Preparation of N-Benzyl-4-bromobenzamide (3da). Using general method A (100 mg of 4-bromo-benzoic acid, $196 \mathrm{mg}$ of triphenylphosphine, $135 \mathrm{mg}$ of $\mathrm{N}$-chlorophthalimide, 160 $\mathrm{mg}$ of benzylamine, and $3 \mathrm{~mL}$ of toluene), the product was purified by column chromatography $\left(R_{f}=0.60, \mathrm{DCM} /\right.$ hexane/ EtOAc $=1: 2.5: 1)$ and isolated in $69 \%$ yield, $100 \mathrm{mg}$. Spectra data matched reported data. ${ }^{42}$

${ }^{1} \mathrm{H}$ NMR (400 MHz, $\left.\mathrm{CDCl}_{3}\right) \delta 7.71-7.60(\mathrm{~m}, 2 \mathrm{H}), 7.61-$ $7.53(\mathrm{~m}, 2 \mathrm{H}), 7.41-7.30(\mathrm{~m}, 5 \mathrm{H}), 4.64(\mathrm{~d}, J=5.6 \mathrm{~Hz}, 2 \mathrm{H})$.

${ }^{13} \mathrm{C}\{1 \mathrm{H}\} \mathrm{NMR}\left(100 \mathrm{MHz}, \mathrm{CDCl}_{3}\right) \delta 166.3,137.9,133.3$, $131.9,128.9,128.6,128,127.8,126.3,44.3$.

Preparation of N-Benzyl-4-bromo-N-methylbenzamide (3db). Using general method A (100 mg of 4-bromo-benzoic acid, $196 \mathrm{mg}$ of triphenylphosphine, $135 \mathrm{mg}$ of $\mathrm{N}$ chlorophthalimide, $120 \mathrm{mg}$ of $\mathrm{N}$-benzylmethylamine, and 3 $\mathrm{mL}$ of $\mathrm{MeCN}$ ), the product was purified by column chromatography $\left(R_{f}=0.48, \mathrm{DCM} /\right.$ hexane $/$ EtOAc $\left.=1: 2.5: 1\right)$ and isolated in $88 \%$ yield, $133 \mathrm{mg}$. Spectra data matched reported data. $^{43}$

${ }^{1} \mathrm{H}$ NMR (400 MHz, $\left.\mathrm{CDCl}_{3}\right) \delta 7.52(\mathrm{~m}, 2 \mathrm{H}), 7.39-7.22(\mathrm{~m}$, $6 \mathrm{H}), 7.22-7.04(\mathrm{~m}, 1 \mathrm{H}), 4.61(\mathrm{~d}, J=97.5 \mathrm{~Hz}, 2 \mathrm{H}), 2.94(\mathrm{~d}, J$ $=68.3 \mathrm{~Hz}, 3 \mathrm{H})$.

${ }^{13} \mathrm{C}\{1 \mathrm{H}\} \mathrm{NMR}\left(100 \mathrm{MHz}, \mathrm{CDCl}_{3}\right) \delta 206.6,135.1,131.7$, 128.9, 128.2, 127.7, 126.6, 124, 55.2, 51, 30.9.

Preparation of N-Benzyl-4-nitrobenzamide (3ea). Using general method A (100 mg of 4-nitro-benzoic acid, $236 \mathrm{mg}$ of triphenylphosphine, $163 \mathrm{mg}$ of $\mathrm{N}$-chlorophthalimide, $192 \mathrm{mg}$ of benzylamine, and $3 \mathrm{~mL}$ of toluene), the product was purified by column chromatography $\left(R_{f}=0.57\right.$, DCM/hexane $/$ EtOAc $=5: 3: 1)$ and isolated in $42 \%$ yield, $66 \mathrm{mg}$. Spectra data matched reported data. ${ }^{44}$

${ }^{1} \mathrm{H}$ NMR (400 MHz, $\mathrm{CDCl}_{3}$ ) $\delta 8.30-8.16(\mathrm{~m}, 2 \mathrm{H}), 8.00-$ $7.89(\mathrm{~m}, 2 \mathrm{H}), 7.40-7.29(\mathrm{~m}, 5 \mathrm{H}), 6.60(\mathrm{~s}, 1 \mathrm{H}), 4.65$ (d, $J=$ $5.6 \mathrm{~Hz}, 2 \mathrm{H})$.

${ }^{13} \mathrm{C}\{1 \mathrm{H}\}$ NMR $\left(100 \mathrm{MHz}, \mathrm{CDCl}_{3}\right) \delta 165.3,149.7,140$, 137.5, 129, 128.2, 128, 127.9, 123.8, 44.5.

Preparation of N-Benzyltetradecanamide (3fa). Using general method A (100 mg of myristic acid, $173 \mathrm{mg}$ of triphenylphosphine, $119 \mathrm{mg}$ of $N$-chlorophthalimide, $141 \mathrm{mg}$ of benzylamine, and $3 \mathrm{~mL}$ of toluene), the product was purified by column chromatography $\left(R_{f}=0.57, \mathrm{DCM} /\right.$ hexane/EtOAc $=5: 3: 1)$ and isolated in $70 \%$ yield, $97 \mathrm{mg}$. Spectra data matched reported data. ${ }^{45}$

${ }^{1} \mathrm{H}$ NMR (400 MHz, $\mathrm{CDCl}_{3}$ ) $\delta 7.32-7.11(\mathrm{~m}, 5 \mathrm{H}), 5.75(\mathrm{~s}$, $J=5.7 \mathrm{~Hz}, 1 \mathrm{H}), 4.36(\mathrm{~d}, J=5.7 \mathrm{~Hz}, 2 \mathrm{H}), 2.19-1.97(\mathrm{~m}, 2 \mathrm{H})$, $1.56(\mathrm{q}, J=7.2 \mathrm{~Hz}, 2 \mathrm{H}), 1.39-0.97(\mathrm{~m}, 19 \mathrm{H}), 0.90-0.55(\mathrm{~m}$, $3 \mathrm{H})$.

${ }^{13} \mathrm{C}\{1 \mathrm{H}\} \mathrm{NMR}\left(100 \mathrm{MHz}, \mathrm{CDCl}_{3}\right) \delta 173.1,138.5,128.7$, $127.8,127.5,123.5,43.6,36.8,31.9,29.7,29.6,29.5,29.4,25.8$, 23.7, 14.1 .

Preparation of N-Benzyl-N-methyltetradecanamide (3fb). Using general method A (100 mg of myristic acid, $173 \mathrm{mg}$ of triphenylphosphine, $119 \mathrm{mg}$ of $\mathrm{N}$-chlorophthalimide, $106 \mathrm{mg}$ of $N$-benzylmethylamine, and $3 \mathrm{~mL}$ of $\mathrm{MeCN}$ ), the product was purified by column chromatography $\left(R_{f}=0.63, \mathrm{DCM} /\right.$ hexane $/$ EtOAc $=5: 3: 1)$ and isolated in $80 \%$ yield, $116 \mathrm{mg}$.

${ }^{1} \mathrm{H} \mathrm{NMR}\left(400 \mathrm{MHz}, \mathrm{CDCl}_{3}\right) \delta 7.39-7.03(\mathrm{~m}, 5 \mathrm{H}), 4.56(\mathrm{~d}$, $J=24.3 \mathrm{~Hz}, 2 \mathrm{H}), 2.92(\mathrm{~d}, J=10.7 \mathrm{~Hz}, 3 \mathrm{H}), 2.42-2.27(\mathrm{~m}$, $2 \mathrm{H}), 1.67(\mathrm{~m}, 2 \mathrm{H}), 1.41-1.11(\mathrm{~m}, 22 \mathrm{H}), 0.94-0.72(\mathrm{~m}, 3 \mathrm{H})$.

${ }^{13} \mathrm{C}\{1 \mathrm{H}\} \mathrm{NMR}\left(100 \mathrm{MHz}, \mathrm{CDCl}_{3}\right) \delta 173.7,173.3,137.7$, 128.9, 128.6, 128, 127.6, 127.3, 126.3, 53.4, 50.8, 34.8, 33.9, 33.6, 33.2, 31.9, 29.7, 29.6, 29.5, 29.4, 25.5, 25.2, 22.7, 14.1 . 
HRMS (ESI): $[\mathrm{M}+\mathrm{H}]^{+}$calcd for $\mathrm{C}_{22} \mathrm{H}_{38} \mathrm{NO}^{+}, 332.2948 \mathrm{~m} /$ $z$; found, $332.2886 \mathrm{~m} / z$.

IR $\left(\mathrm{cm}^{-1}\right)$ : 2930, 2856, 1653, 1457, 1265, 1094.

Preparation of tert-Butyl 3-(3-((( (9H-fluoren-9-yl)methoxy)carbonyl)amino)-4-(benzylamino)-4-oxobutyl)$1 \mathrm{H}$-indole-1-carboxylate (3ga). Using general method A (100 $\mathrm{mg}$ of Fmoc-Trp(Boc)-OH, $76 \mathrm{mg}$ of triphenylphosphine, 53 $\mathrm{mg}$ of $\mathrm{N}$-chlorophthalimide, $61 \mathrm{mg}$ of benzylamine, and $3 \mathrm{~mL}$ of toluene), the product was purified by column chromatography $\left(R_{f}=0.83, \mathrm{DCM} /\right.$ hexane $\left./ \mathrm{EtOAc}=2: 1: 1\right)$ and isolated in $54 \%$ yield, $63 \mathrm{mg}$.

${ }^{1} \mathrm{H}$ NMR (400 MHz, $\left.\mathrm{CDCl}_{3}\right) \delta 8.07(\mathrm{~d}, J=8.2 \mathrm{~Hz}, 1 \mathrm{H})$, $7.67(\mathrm{~d}, J=7.6 \mathrm{~Hz}, 2 \mathrm{H}) 7.6-7.09(\mathrm{~m}, 14 \mathrm{H}), 6.87(\mathrm{~m}, 2 \mathrm{H})$, $5.66(\mathrm{~d}, J=146.0 \mathrm{~Hz}, 2 \mathrm{H}), 4.51-3.85(\mathrm{~m}, 5 \mathrm{H}), 3.43-2.82(\mathrm{~m}$, $2 \mathrm{H}), 1.57$ (s, 9H).

${ }^{13} \mathrm{C}\{1 \mathrm{H}\}$ NMR $\left(100 \mathrm{MHz}, \mathrm{CDCl}_{3}\right) \delta 170.6,143.7,141.3$, $137.3,128.6,127.8,127.6,127.5,127.1,125,124.8,124.4,123$, 120, 119, 115.4, 83.9, 67.2, 47.1, 43.7, 28.6, 28.2.

HRMS (ESI): $[\mathrm{M}+\mathrm{H}]^{+}$calcd for $\mathrm{C}_{38} \mathrm{H}_{38} \mathrm{~N}_{3} \mathrm{O}_{5}{ }^{+}, 616.2806$ $\mathrm{m} / z$; found, $616.2550 \mathrm{~m} / z$.

IR $\left(\mathrm{cm}^{-1}\right): 3304,3064,1734,1684,1649,1549,1453,1374$, 1080.

Preparation of N-Benzyl-4-(trifluoromethyl)benzamide (3ha). Using general method A (100 mg of 4-triflourobenzoic acid, $210 \mathrm{mg}$ of triphenylphosphine, $145 \mathrm{mg}$ of $\mathrm{N}$ chlorophthalimide, $170 \mathrm{mg}$ of benzylamine, and $3 \mathrm{~mL}$ of toluene), the product was purified by column chromatography $\left(R_{f}=0.47, \mathrm{DCM} /\right.$ hexane/EtOAc $\left.=7: 3: 1\right)$ and isolated in $40 \%$ yield, $59 \mathrm{mg}$. Spectra data matched reported data. ${ }^{46}$

${ }^{1} \mathrm{H} \mathrm{NMR}\left(400 \mathrm{MHz}, \mathrm{CDCl}_{3}\right) \delta 7.91(\mathrm{~d}, J=8.0 \mathrm{~Hz}, 2 \mathrm{H})$, $7.70(\mathrm{~d}, J=8.1 \mathrm{~Hz}, 2 \mathrm{H}), 7.50-7.16(\mathrm{~m}, 5 \mathrm{H}), 6.55(\mathrm{~s}, 1 \mathrm{H})$, $4.67(\mathrm{~d}, J=5.6 \mathrm{~Hz}, 2 \mathrm{H})$.

${ }^{13} \mathrm{C}\{1 \mathrm{H}\} \mathrm{NMR}\left(100 \mathrm{MHz}, \mathrm{CDCl}_{3}\right) \delta 166.1,137.8,137.7$, $128.9,128,127.9,127.5,125.7,125.6,44.3$.

Preparation of N-Benzyl-N-methyl-4-(trifluoromethyl)benzamide (3hb). Using general method A (100 mg of 4triflourobenzoic acid, $210 \mathrm{mg}$ of triphenylphosphine, $145 \mathrm{mg}$ of $\mathrm{N}$-chlorophthalimide, $129 \mathrm{mg}$ of $\mathrm{N}$-benzylmethylamine, and $3 \mathrm{~mL}$ of $\mathrm{MeCN}$ ), the product was purified by column chromatography $\left(R_{f}=0.45, \mathrm{DCM} /\right.$ hexane $/$ EtOAc $\left.=10: 3: 1\right)$ and isolated in $73 \%$ yield, $113 \mathrm{mg}$. Spectra data matched reported data. $^{26}$

${ }^{1} \mathrm{H}$ NMR (400 MHz, $\left.\mathrm{CDCl}_{3}\right) \delta 7.58(\mathrm{~m}, 2 \mathrm{H}), 7.49$ (d, m, $2 \mathrm{H}), 7.26(\mathrm{~m}, 4 \mathrm{H}), 7.07(\mathrm{~m}, 1 \mathrm{H}), 4.54(\mathrm{~d}, J=117.4 \mathrm{~Hz}, 2 \mathrm{H})$, $2.87(\mathrm{~d}, J=87.4 \mathrm{~Hz}, 3 \mathrm{H})$,

${ }^{13} \mathrm{C}\{1 \mathrm{H}\}$ NMR $\left(100 \mathrm{MHz}, \mathrm{CDCl}_{3}\right) \delta 170.8,139.9,136.7$, $136.1,131.8,131.4,129,128.9,127.9,127.7,55,50.9,36.9$, 33.3.

Preparation of N-Benzyl-2-(4-isobutylphenyl)propanamide (3ia). Using general method A (100 mg of 2(4-isobutylphenyl)propanoic acid, $194 \mathrm{mg}$ of triphenylphosphine, $134 \mathrm{mg}$ of $\mathrm{N}$-chlorophthalimide, $157 \mathrm{mg}$ of benzylamine, and $3 \mathrm{~mL}$ of toluene), the product was purified by column chromatography $\left(R_{f}=0.59, \mathrm{DCM} /\right.$ hexane $/$ EtOAc $=$ $7: 3: 1)$ and isolated in $50 \%$ yield, $71 \mathrm{mg}$. Spectra data matched reported data. ${ }^{47}$

${ }^{1} \mathrm{H}$ NMR (400 MHz, $\mathrm{CDCl}_{3}$ ) $\delta$ 7.20-7.09 (m, 5H), 7.06$6.98(\mathrm{~m}, 4 \mathrm{H}), 5.66(\mathrm{~s}, 1 \mathrm{H}), 4.29(\mathrm{~d}, J=5.8 \mathrm{~Hz}, 2 \mathrm{H}), 3.50(\mathrm{q}, J$ $=7.2 \mathrm{~Hz}, 1 \mathrm{H}), 2.37(\mathrm{~d}, J=7.2 \mathrm{~Hz}, 2 \mathrm{H}), 1.76(\mathrm{~m}, 1 \mathrm{H}), 1.46(\mathrm{~d}$, $J=7.2 \mathrm{~Hz}, 3 \mathrm{H}), 0.81(\mathrm{~d}, J=6.6 \mathrm{~Hz}, 6 \mathrm{H})$.

${ }^{13} \mathrm{C}\{1 \mathrm{H}\} \mathrm{NMR}\left(100 \mathrm{MHz}, \mathrm{CDCl}_{3}\right) \delta 174.4,140.8,138.5$, 129.7, 128.6, 127.4, 127.3, 46.8, 45, 43.5, 30.2, 22.4, 18.5 .
Preparation of N-Benzyl-2-(4-isobutylphenyl)propanamide (3ib). Using general method A (100 mg of 2(4-isobutylphenyl)propanoic acid, $194 \mathrm{mg}$ of triphenylphosphine, $134 \mathrm{mg}$ of $\mathrm{N}$-chlorophthalimide, $116 \mathrm{mg}$ of $\mathrm{N}$ benzylmethylamine, and $3 \mathrm{~mL}$ of $\mathrm{MeCN}$ ), the product was purified by column chromatography $\left(R_{f}=0.68, \mathrm{DCM} /\right.$ hexane/ EtOAc $=7: 3: 1)$ and isolated in $80 \%$ yield, $120 \mathrm{mg}$.

${ }^{1} \mathrm{H}$ NMR (400 MHz, $\mathrm{CDCl}_{3}$ ) $\delta 7.37-7.16(\mathrm{~m}, 6 \mathrm{H}), 7.12$ (m, 2H), 7.05-7.01 (m, $1 \mathrm{H}), 4.85-4.28(\mathrm{~m}, 2 \mathrm{H}), 3.91(\mathrm{~m}$, $1 \mathrm{H}), 2.89$ (d, $J=47.2 \mathrm{~Hz}, 3 \mathrm{H}), 2.48(\mathrm{~d}, J=7.1 \mathrm{~Hz}, 2 \mathrm{H}), 1.88$ $(\mathrm{m}, 1 \mathrm{H}), 1.50(\mathrm{~m}, 3 \mathrm{H}), 0.93(\mathrm{dd}, J=6.6,2.6 \mathrm{~Hz}, 6 \mathrm{H})$.

${ }^{13} \mathrm{C}\{1 \mathrm{H}\} \mathrm{NMR}\left(100 \mathrm{MHz}, \mathrm{CDCl}_{3}\right) \delta 174,140.3,140,139.2$, $138.9,137.6,136.9,129.6,129.5,128.8,128.5,127.9,127.5$, 127.2, 127, 126.5, 52.9, 51.2, 45, 43.1, 42.8, 34.8, 34.1, 30.2, 22.4, 21.1, 20.8.

HRMS (ESI): $[\mathrm{M}+\mathrm{H}]^{+}$calcd for $\mathrm{C}_{21} \mathrm{H}_{28} \mathrm{NO}^{+}, 310.2165 \mathrm{~m} /$ $z$; found, $310.2115 \mathrm{~m} / z$.

IR $\left(\mathrm{cm}^{-1}\right): 3048,2948,2865,1740,1648,1449,1267,1059$. Preparation of N-Benzyl-2-methyl-2-phenylpropanamide (3ja). Using general method A (100 mg of 2-phenylisobutyric acid, $241 \mathrm{mg}$ of triphenylphosphine, $167 \mathrm{mg}$ of $\mathrm{N}$ chlorophthalimide, $196 \mathrm{mg}$ of benzylamine, and $3 \mathrm{~mL}$ of toluene), the product was purified by column chromatography $\left(R_{f}=0.49, \mathrm{DCM} /\right.$ hexane $/$ EtOAc $\left.=7: 3: 1\right)$ and isolated in $43 \%$ yield, $66 \mathrm{mg}$. Spectra data matched reported data. ${ }^{48}$

${ }^{1} \mathrm{H} \mathrm{NMR}\left(400 \mathrm{MHz}, \mathrm{CDCl}_{3}\right) \delta 7.33-7.23(\mathrm{~m}, 4 \mathrm{H}), 7.22-$ $7.12(\mathrm{~m}, 3 \mathrm{H}), 7.07-7.00(\mathrm{~m}, 2 \mathrm{H}), 5.39(\mathrm{~s}, 1 \mathrm{H}), 4.29(\mathrm{~d}, J=$ $5.8 \mathrm{~Hz}, 2 \mathrm{H}), 1.53(\mathrm{~s}, 6 \mathrm{H})$.

${ }^{13} \mathrm{C}\{1 \mathrm{H}\} \mathrm{NMR}\left(100 \mathrm{MHz}, \mathrm{CDCl}_{3}\right) \delta 177.3,145.1,138.6$, 128.8, 128.6, 127.3, 127.1, 126.5, 47.1, 43.7, 27.1.

Preparation of $\mathrm{N}$-Benzyl-N,2-dimethyl-2-phenylpropanamide (3jb). Using general method A (100 mg of 2phenylisobutyric acid, $241 \mathrm{mg}$ of triphenylphosphine, $167 \mathrm{mg}$ of $\mathrm{N}$-chlorophthalimide, $148 \mathrm{mg}$ of $\mathrm{N}$-benzylmethylamine, and $3 \mathrm{~mL}$ of $\mathrm{MeCN}$ ), the product was purified by column chromatography $\left(R_{f}=0.65, \mathrm{DCM} /\right.$ hexane $/$ EtOAc $\left.=7: 3: 1\right)$ and isolated in $94 \%$ yield, $153 \mathrm{mg}$. Spectra data matched reported data.

${ }^{1} \mathrm{H}$ NMR (400 MHz, $\mathrm{CDCl}_{3}$ ) $\delta 7.54-6.61(\mathrm{~m}, 10 \mathrm{H}), 5.10-$ $3.69(\mathrm{~m}, 2 \mathrm{H}), 2.82-2.26(\mathrm{~m}, 3 \mathrm{H}), 1.50(\mathrm{~s}, 6 \mathrm{H})$.

${ }^{13} \mathrm{C}\{1 \mathrm{H}\} \mathrm{NMR}\left(100 \mathrm{MHz}, \mathrm{CDCl}_{3}\right) \delta 176.3,146.4,128.9$, $128.5,127.2,126.4,124.9,47.2,28.4$.

HRMS (ESI): $[\mathrm{M}+\mathrm{H}]^{+}$calcd for $\mathrm{C}_{18} \mathrm{H}_{22} \mathrm{NO}^{+}, 268.1696 \mathrm{~m} /$ $z$; found, $268.1660 \mathrm{~m} / z$.

IR $\left(\mathrm{cm}^{-1}\right):$ 3100, 2990, 2925, 2249, 1714, 1648, 1400, 1088.

Preparation of $\mathrm{N}$-(3-Isopropoxyphenyl)-2-methylbenzamide (3kc). Using general method A (100 mg of $o$-toluic acid, $322 \mathrm{mg}$ of triphenylphosphine, $291 \mathrm{mg}$ of $\mathrm{N}$ chlorophthalimide, $335 \mathrm{mg}$ of 3-isopropoxyaniline, and $3 \mathrm{~mL}$ of toluene), the product was purified by column chromatography $\left(R_{f}=0.54, \mathrm{DCM} /\right.$ hexane $/$ EtOAc $\left.=10: 3: 1\right)$ and isolated in $55 \%$ yield, $109 \mathrm{mg}$. Spectra data matched reported data. ${ }^{17 \mathrm{c}}$

${ }^{1} \mathrm{H}$ NMR $\left(400 \mathrm{MHz}, \mathrm{CDCl}_{3}\right) \delta 7.65(\mathrm{~s}, 1 \mathrm{H}), 7.33-7.24(\mathrm{~m}$, $2 \mathrm{H}), 7.24-7.16(\mathrm{~m}, 1 \mathrm{H}), 7.14-7.07(\mathrm{~m}, 3 \mathrm{H}), 7.01-6.94(\mathrm{~m}$, $1 \mathrm{H}), 6.60$ (dd, $J=8.3,2.4 \mathrm{~Hz}, 1 \mathrm{H}), 4.49$ (sept, $J=6.2 \mathrm{~Hz}$, $1 \mathrm{H}), 2.35$ (s, $3 \mathrm{H}), 1.23(\mathrm{~d}, J=6.1 \mathrm{~Hz}, 6 \mathrm{H})$.

${ }^{13} \mathrm{C}\{1 \mathrm{H}\} \mathrm{NMR}\left(100 \mathrm{MHz}, \mathrm{CDCl}_{3}\right) \delta 168.1,158.6,139.3$, $136.4,131.2,130.2,129.8,126.7,125.9,112.2,111.9,107.6$, 70, 60.4, 22.1, 19.8, 14.2.

Preparation of 2-Benzoylisoindoline-1,3-dione (4a). Using general method B (100 mg of benzoic acid, $323 \mathrm{mg}$ of triphenylphosphine, $223 \mathrm{mg}$ of $\mathrm{N}$-chlorophthalimide, $150 \mathrm{mg}$ of DMAP, and $3 \mathrm{~mL}$ of toluene), the product was purified by 
column chromatography $\left(R_{f}=0.4, \mathrm{DCM} /\right.$ hexane $\left.=2: 1\right)$ and isolated in $60 \%$ yield, $123 \mathrm{mg}$. Spectra data matched reported data. 49

${ }^{1} \mathrm{H}$ NMR (400 MHz, $\left.\mathrm{CDCl}_{3}\right) \delta 7.98(\mathrm{~m}, 2 \mathrm{H}), 7.90-7.82$ (m, $4 \mathrm{H}), 7.72-7.61(\mathrm{~m}, 1 \mathrm{H}), 7.56-7.43(\mathrm{~m}, 2 \mathrm{H})$.

${ }^{13} \mathrm{C}\{1 \mathrm{H}\} \mathrm{NMR}\left(100 \mathrm{MHz}, \mathrm{CDCl}_{3}\right) \delta 167.9165 .9$, 135.3, $134.5,131.5,130.5,128.7,124.5$.

Preparation of 2-(4-Methoxybenzoyl)isoindoline-1,3dione (4b). Using general method B (100 mg of 4-methoxybenzoic acid, $259 \mathrm{mg}$ of triphenylphosphine, $179 \mathrm{mg}$ of $\mathrm{N}$ chlorophthalimide, $120 \mathrm{mg}$ of DMAP, and $3 \mathrm{~mL}$ of toluene), the product was purified by column chromatography $\left(R_{f}=0.7\right.$, $\mathrm{DCM} /$ hexane/EtOAc $=5: 3: 1)$ and isolated in $44 \%$ yield, 81 mg. Spectra data matched reported data. ${ }^{50}$

${ }^{1} \mathrm{H}$ NMR (400 MHz, $\left.\mathrm{CDCl}_{3}\right) \delta 7.97(\mathrm{~m}, 2 \mathrm{H}), 7.90-7.81$ (m, 4H), $6.96(\mathrm{~d}, J=8.9 \mathrm{~Hz}, 2 \mathrm{H}), 3.89(\mathrm{~s}, 3 \mathrm{H})$.

${ }^{13} \mathrm{C}\{1 \mathrm{H}\} \mathrm{NMR}\left(100 \mathrm{MHz}, \mathrm{CDCl}_{3}\right) \delta 166.1,164.7,135.1$, 133.2, 131.7, 125, 124.4, 114.1, 55.6.

Preparation of 2-(4-(Benzyloxy)benzoyl)isoindoline-1,3dione (4c). Using general method B $100 \mathrm{mg}$ of 4-(benzyloxy)benzoic acid, $173 \mathrm{mg}$ of triphenylphosphine, $120 \mathrm{mg}$ of $\mathrm{N}$ chlorophthalimide, $80 \mathrm{mg}$ of DMAP, and $3 \mathrm{~mL}$ of toluene), the product was purified by column chromatography $\left(R_{f}=0.7\right.$, $\mathrm{DCM} /$ hexane $/$ EtOAc $=5: 3: 1)$ and isolated in $70 \%$ yield, 110 $\mathrm{mg}$.

${ }^{1} \mathrm{H}$ NMR (400 MHz, $\left.\mathrm{CDCl}_{3}\right) \delta 7.97(\mathrm{~m}, 2 \mathrm{H}), 7.91-7.81$ (m, 4H), 7.13-6.97 (m, 2H), 5.15 (s, 2H).

${ }^{13} \mathrm{C}\{1 \mathrm{H}\} \mathrm{NMR}\left(100 \mathrm{MHz}, \mathrm{CDCl}_{3}\right) \delta 165.6,163.5,135.9$, $135.1,133.2,131.7,128.8,128.4,127.5,125.2,124.4,115$, 70.4

HRMS (ESI): $[\mathrm{M}+\mathrm{H}]^{+}$calcd for $\mathrm{C}_{22} \mathrm{H}_{16} \mathrm{NO}_{4}{ }^{+}, 358.1074 \mathrm{~m} /$ $z$; found, $358.1101 \mathrm{~m} / z$.

IR $\left(\mathrm{cm}^{-1}\right): 3078,3032,2946,1784,1683,1510,1105$.

Preparation of 2-(2-Methyl-2-phenylpropanoyl)isoindoline-1,3-dione (4d). Using general method B (100 $\mathrm{mg}$ of 2-phenyl isobutyric acid, $240 \mathrm{mg}$ of triphenylphosphine, $166 \mathrm{mg}$ of $\mathrm{N}$-chlorophthalimide, $112 \mathrm{mg}$ of DMAP, and $3 \mathrm{~mL}$ of toluene), the product was purified by column chromatography $\left(R_{f}=0.6\right.$, EtOAc/hexane $\left.=3: 5\right)$ and isolated in $48 \%$ yield, $86 \mathrm{mg}$.

${ }^{1} \mathrm{H}$ NMR (400 MHz, $\left.\mathrm{CDCl}_{3}\right) \delta 7.82-7.78(\mathrm{~m}, 2 \mathrm{H}), 7.76-$ $7.71(\mathrm{~m}, 2 \mathrm{H}), 7.40-7.18(\mathrm{~m}, 5 \mathrm{H}), 1.81(\mathrm{~s}, 6 \mathrm{H})$.

${ }^{13} \mathrm{C}\{1 \mathrm{H}\} \mathrm{NMR}\left(100 \mathrm{MHz}, \mathrm{CDCl}_{3}\right) \delta 178.9,165.1,142.5$, $134.9,131.3,128.3,127,126.5,124.1,51.5,26.9$.

HRMS (ESI): $[\mathrm{M}+\mathrm{H}]^{+}$calcd for $\mathrm{C}_{18} \mathrm{H}_{16} \mathrm{NO}_{3}^{+}, 358.1074 \mathrm{~m} /$ $z$; found, $358.1101 \mathrm{~m} / z$

IR $\left(\mathrm{cm}^{-1}\right): 3100,3060,2960,2940,2000,1790,1760,1500$, 1060.

\section{ASSOCIATED CONTENT}

\section{SI Supporting Information}

The Supporting Information is available free of charge at https://pubs.acs.org/doi/10.1021/acsomega.0c02309.

${ }^{1} \mathrm{H}$ and ${ }^{13} \mathrm{C}\left\{{ }^{1} \mathrm{H}\right\}$ NMR spectra for all aminated products (PDF)

\section{AUTHOR INFORMATION}

\section{Corresponding Author}

Sébastien Laulhé - Department of Chemistry and Chemical Biology, Indiana University-Purdue University Indianapolis (IUPUI), Indianapolis, Indiana 46202, United States; 다이.org/0000-0003-4510-1916; Email: slaulhe@ iupui.edu

\section{Authors}

Charles D. Irving - Department of Chemistry and Chemical Biology, Indiana University-Purdue University Indianapolis (IUPUI), Indianapolis, Indiana 46202, United States

Jack T. Floreancig - Department of Chemistry and Chemical Biology, Indiana University-Purdue University Indianapolis (IUPUI), Indianapolis, Indiana 46202, United States

Complete contact information is available at:

https://pubs.acs.org/10.1021/acsomega.0c02309

\section{Funding}

This publication was made possible, in part, with support from the Indiana Clinical and Translational Sciences Institute funded, in part by grant no. UL1TR002529 from the National Institutes of Health, National Center for Advancing Translational Sciences, Clinical and Translational Sciences Award. The content is solely the responsibility of the authors and does not necessarily represent the official views of the National Institutes of Health. Start-up funding from Indiana University-Purdue University Indianapolis (IUPUI) was also used to support this research. National Institute of Dental \& Craniofacial Research grant no. 1R21DE029156-01. The authors declare no competing financial interest.

Notes

The authors declare no competing financial interest.

\section{ACKNOWLEDGMENTS}

We gratefully acknowledge IUPUI for financial support. J.T.F. is also grateful for financial support from the Center for Research and Learning (CRL) at IUPUI (Undergraduate Research Opportunities; MURI Projects).

\section{REFERENCES}

(1) ((a)) Greenberg, A.; Breneman, C. M.; Liebman, J. F. The Amide Linkage: Selected Structural Aspects in Chemistry, Biochemistry, and Materials Science; Wiley-Interscience: 2000. ((b)) Wieland, T.; Bodanszky, M. The World of Peptides: A Brief History of Peptide Chemistry; Springer: 1991. (c) Suresh Babu, V. V. One Hundred Years of Peptide Chemistry. Resonance 2011, 16, 640-647.

(2) Carey, J. S.; Laffan, D.; Thomson, C.; Williams, M. T. Analysis of the Reactions Used for the Preparation of Drug Candidate Molecules. Org. Biomol. Chem. 2006, 4, 2337-2347.

(3) Tsikolia, M.; Bernier, U. R.; Coy, M. R.; Chalaire, K. C.; Becnel, J. J.; Agramonte, N. M.; Tabanca, N.; Wedge, D. E.; Clark, G. G.; Linthicum, K. J.; Swale, D. R.; Bloomquist, J. R. Insecticidal, Repellent and Fungicidal Properties of Novel Trifluoromethylphenyl Amides. Pestic. Biochem. Physiol. 2013, 107, 138-147.

(4) (a) Ocheje, M. U.; Charron, B. P.; Cheng, Y.-H.; Chuang, C.-H.; Soldera, A.; Chiu, Y.-C.; Rondeau-Gagné, S. Amide-Containing Alkyl Chains in Conjugated Polymers: Effect on Self-Assembly and Electronic Properties. Macromolecules 2018, 51, 1336-1344. (b) McGeoch, J. E. M.; McGeoch, M. W. Polymer Amide as an Early Topology. PLoS One 2014, 9, No. e103036. (c) Deming, T. J. Synthetic polypeptides for biomedical applications. Prog. Polym. Sci. 2007, 32, 858-875. ((d)) Rutledge, R. D.; Wright, D. W. Biomineralization: Peptide-Mediated Synthesis of Materials; Wiley \& Sons: 2009.

(5) Brown, D. G.; Boström, J. Analysis of Past and Present Synthetic Methodologies on Medicinal Chemistry: Where Have All the New Reactions Gone? J. Med. Chem. 2016, 59, 4443-4458.

(6) Recent reviews on coupling reagents: (a) Dunetz, J. R.; Magano, J.; Weisenburger, G. A. Large-Scale Applications of Amide Coupling 
Reagents for the Synthesis of Pharmaceuticals. Org. Process Res. Dev. 2016, 20, 140-177. (b) Valeur, E.; Bradley, M. Amide Bond Formation: Beyond the Myth of Coupling Reagents. Chem. Soc. Rev. 2009, 38, 606-631.

(7) Seminal work: Dawson, P. E.; Muir, T. W.; Clark-Lewis, I.; Kent, S. B. Synthesis of Proteins by Native Chemical Ligation. Science 1994, 266, 776-779.

(8) Seminal work: Merrifield, R. B. Solid Phase Peptide Synthesis. I. The Synthesis of a Tetrapeptide. J. Am. Chem. Soc. 1963, 85, 21492154.

(9) (a) El Dine, T. M.; Erb, W.; Berhault, Y.; Rouden, J.; Blanchet, J. Catalytic Chemical Amide Synthesis at Room Temperature: One More Step Toward Peptide Synthesis. J. Org. Chem. 2015, 80, 45324544. (b) Sawant, D. N.; Bagal, D. B.; Ogawa, S.; Selvam, K.; Saito, S. Diboron-Catalyzed Dehydrative Amidation of Aromatic Carboxylic Acids with Amines. Org. Lett. 2018, 20, 4397-4400. (c) Ishihara, K.; Ohara, S.; Yamamoto, H. 3,4,5-Trifluorobenzeneboronic Acid as an Extremely Active Amidation Catalyst. J. Org. Chem. 1996, 61, 41964197. (d) Al-Zoubi, R. M.; Marion, O.; Hall, D. G. Direct and WasteFree Amidations and Cycloadditions by Organocatalytic Activation of Carboxylic Acids at Room Temperature. Angew. Chem., Int. Edn. 2008, 47, 2876-2879. (e) Charville, H.; Jackson, D.; Hodges, G.; Whiting, A. The Thermal and Boron-Catalysed Direct Amide Formation Reactions: Mechanistically Understudied Yet Important Processes. Chem. Commun. 2010, 46, 1813-1823.

(10) (a) Pattabiraman, V. R.; Bode, J. W. Rethinking Amide Bond Synthesis. Nature 2011, 480, 471-479. (b) Humphrey, J. M.; Chamberlin, A. R. Chemical Synthesis of Natural Product Peptides: Coupling Methods for the Incorporation of Noncoded Amino Acids into Peptides. Chem. Rev. 1997, 97, 2243-2266.

(11) (a) Williams, A.; Ibrahim, I. T. Carbodiimide Chemistry: Recent Advances. Chem. Rev. 1981, 81, 589-636. (b) Mikozxllajczyk, M.; Kiezxllbasiński, P. Recent Developments in the Carbodiimide Chemistry. Tetrahedron 1981, 37, 233-284.

(12) (a) Castro, B.; Dormoy, J. R. Reactions des Sels de Trisdimethylamino(pseudo)halophosphonium sur les Acides Carboxyliques. Tetrahedron Lett. 1973, 14, 3243-3246. (b) Castro, B.; Dormoy, J. R.; Evin, G.; Selve, C. Reactifs de Couplage Peptidique I (1) - l'hexafluorophosphate de Benzotriazolyl N-oxytrisdimethylamino Phosphonium (B.O.P.). Tetrahedron Lett. 1975, 16, 1219-1222. (c) Coste, J.; Le-Nguyen, D.; Castro, B. PyBOP®: A New Peptide Coupling Reagent Devoid of Toxic By-product. Tetrahedron Lett. 1990, 31, 205-208. (d) Wang, W.; McMurray, J. S. A Selective Method for the Preparation of Primary Amides: Synthesis of Fmoc-14-carboxamidophenylalanine and Other Compounds. Tetrahedron Lett. 1999, 40, 2501-2504. (e) de Figueiredo, R. M.; Suppo, J.-S.; Campagne, J.-M. Nonclassical Routes for Amide Bond Formation. Chem. Rev. 2016, 116, 12029-12122.

(13) (a) Wehrstedt, K. D.; Wandrey, P. A.; Heitkamp, D. Explosive Properties of 1-Hydroxybenzotriazoles. J. Hazard. Mater. 2005, 126, 1-7. (b) Kang, F.-A.; Sui, Z.; Murray, W. V. Pd-Catalyzed Direct Arylation of Tautomerizable Heterocycles with Aryl Boronic Acids Via $\mathrm{C}-\mathrm{OH}$ Bond Activation Using Phosphonium Salts. J. Am. Chem. Soc. 2008, 130, 11300-11302.

(14) Gasonoo, M.; Thom, Z. W.; Laulhé, S. Regioselective $\alpha$ Amination of Ethers Using Stable $\mathrm{N}$-Chloroimides and Lithium tertButoxide. J. Org. Chem. 2019, 84, 8710-8716.

(15) (a) Weinberger, C.; Hines, R.; Zeller, M.; Rosokha, S. V. Continuum of Covalent to Intermolecular Bonding in the HalogenBonded Complexes of 1,4-Diazabicyclo[2.2.2] octane with BromineContaining Electrophiles. Chem. Commun. 2018, 54, 8060-8063. (b) Watson, B.; Grounds, O.; Borley, W.; Rosokha, S. V. Resolving the halogen vs. hydrogen bonding dichotomy in solutions: intermolecular complexes of trihalomethanes with halide and pseudohalide anions. Phys. Chem. Chem. Phys. 2018, 20, 2199922007.

(16) (a) Kumar, A.; Akula, H. K.; Lakshman, M. K. Simple Synthesis of Amides and Weinreb Amides Using $\mathrm{PPh}_{3}$ or Polymer-Supported $\mathrm{PPh}_{3}$ and Iodine. Eur. J. Org. Chem. 2010, 14, 2709-2715. (b) Matveeva, E. D.; Podrugina, T. A.; Sandakova, N. G.; Zefirov, N. S. Triphenylphosphine-2,4,4,6-Tetrabromo-2,5-cyclohexadienone Complex as a Reagent for Preparation of Carboxylic Acid Bromides. Russ. J. Org. 2004, 40, 1469-1472. (c) Duangkamol, C.; Jaita, S.; Wangngae, S.; Phakhodee, W.; Pattarawarapan, M. An Efficient Mechanochemical Synthesis of Amides and Dipeptides Using 2,4,6trichloro-1,3,5-triazine and PPh3. RSC Adv. 2015, 5, 52624-52628. (d) Wang, S.-P.; Cheung, C. W.; Ma, J.-A. Direct Amidation of Carboxylic Acids with Nitroarenes. J. Org. Chem. 2019, 84, 1392213934

(17) (a) Rouhi-Saadabad, H.; Akhlaghinia, B. A One-Pot, Fast and Efficient Amidation of Carboxylic Acids, $\alpha$-Amino Acids and Sulfonic Acids Using PPh3/N-chlorobenzotriazole system. Phosphorus Sulfur Relat. Elem. 2015, 190, 1703-1714. (b) Munoz, S. B.; Dang, H.; Ispizua-Rodriguez, X.; Mathew, T.; Prakash, G. K. S. Direct Access to Acyl Fluorides from Carboxylic Acids Using a Phosphine/Fluoride Deoxyfluorination Reagent System. Org. Lett. 2019, 21, 1659-1663. (c) Yang, Z.; Chen, S.; Yang, F.; Zhang, C.; Dou, Y.; Zhou, Q.; Yan, Y.; Tang, L. $\mathrm{PPh}_{3}$ /Selectfluor-Mediated Transformation of Carboxylic Acids into Acid Anhydrides and Acyl Fluorides and Its Application in Amide and Ester Synthesis. Eur. J. Org. Chem. 2019, 2019, 59986002. (d) Frøyen, P. The Conversion of Carboxylic Acids Into Amides Via NCS/Triphenylphosphine. Synth. Commun. 1995, 25, 959-968.

(18) Tolman, C. A. Phosphorus Ligand Exchange Equilibriums on Zero-valent Nickel. Dominant Role for Steric Effects. J. Am. Chem. Soc. 1970, 92, 2956-2965.

(19) (a) Enright, R. N.; Grinde, J. L.; Wurtz, L. I.; Paeth, M. S.; Wittman, T. R.; Cliff, E. R.; Sankari, Y. T.; Henningsen, L. T.; Tan, C.; Scanlon, J. D.; Willoughby, P. H. Synthesis of N,O-acetals by net amide $\mathrm{CN}$ bond insertion of aldehydes into $\mathrm{N}$-acyl phthalimides and N-acyl azoles. Tetrahedron 2016, 72, 6397-6408. (b) Tanaka, J.-i.; Higa, T. Zampanolide, A New Cytotoxic Marcrolide from a Marine Sponge. Tetrahedron Lett. 1996, 37, 5535-5538. (c) Cichewicz, R. H.; Valeriote, F. A.; Crews, P. Psymberin, A Potent Sponge-Derived Cytotoxin from Psammocinia Distantly Related to the Pederin Family. Org. Lett. 2004, 6, 1951-1954. (d) Piel, J.; Butzke, D.; Fusetani, N.; Hui, D.; Platzer, M.; Wen, G.; Matsunaga, S. Exploring the Chemistry of Uncultivated Bacterial Symbionts: Antitumor Polyketides of the Pederin Family. J. Nat. Prod. 2005, 68, 472-479.

(20) (a) Hassanzadeh, F.; Rabbani, M.; Khodarahmi, G. A.; Moosavi, M. Synthesis and Evaluation of the Anxiolytic Activity of Some Phthalimide Derivatives in Mice Model of Anxiety. Iran J Pharm Res. 2012, 11, 109-115. (b) Rateb, H. S.; Ahmed, H. E. A.; Ahmed, S.; Ihmaid, S.; Afifi, T. H. Discovery Of Novel Phthalimide Analogs: Synthesis, Antimicrobial and Antitubercular Screening With Molecular Docking Studies. EXCLI J. 2016, 15, 781-796.

(21) (a) Rahman, M.; Buchspies, J.; Szostak, M. N-Acylphthalimides: Efficient Acyl Coupling Reagents in Suzuki-Miyaura CrossCoupling by $\mathrm{N}-\mathrm{C}$ Cleavage Catalyzed by Pd-PEPPSI Precatalysts. Catalysts 2019, 9, 129. (b) Shi, S.; Szostak, M. Nickel-Catalyzed Negishi Cross-Coupling of N-Acylsuccinimides: Stable, Amide-Based, Twist-Controlled Acyl-Transfer Reagents Via N-C Activation. Synthesis 2017, 49, 3602-3608. (c) Shi, S.; Meng, G.; Szostak, M. Synthesis of Biaryls through Nickel-Catalyzed Suzuki-Miyaura Coupling of Amides by Carbon-Nitrogen Bond Cleavage. Angew. Chem., Int. Ed. 2016, 55, 6959-6963. (d) Meng, G.; Szostak, M. Sterically Controlled Pd-Catalyzed Chemoselective Ketone Synthesis via N-C Cleavage in Twisted Amides. Org. Lett. 2015, 17, 43644367. (e) Meng, G.; Szostak, M. General Olefin Synthesis by the Palladium-Catalyzed Heck Reaction of Amides: Sterically Controlled Chemoselective N-C Activation. Angew. Chem., Int. Ed. 2015, 127, 14726-14730. (f) Meng, G.; Szostak, M. Rhodium-Catalyzed C-H Bond Functionalization with Amides by Double $\mathrm{C}-\mathrm{H} / \mathrm{C}-\mathrm{N}$ Bond Activation. Org. Lett. 2016, 18, 796-799. (g) Szostak, R.; Szostak, M. N-Acyl-glutarimides: Resonance and Proton Affinities of RotationallyInverted Twisted Amides Relevant to $\mathrm{N}-\mathrm{C}(\mathrm{O})$ Cross-Coupling. Org. Lett. 2018, 20, 1342-1345. 
(22) Subramani, M.; Rajendran, S. K. Mild, Metal-Free and Protection-Free Transamidation of N-Acyl-2-piperidones to Amino Acids, Amino Alcohols and Aliphatic Amines and Esterification of $\mathrm{N}$ Acyl-2-piperidones. Eur. J. Org. Chem. 2019, 2019, 3677-3686.

(23) Jiang, L.; Yu, J.; Niu, F.; Zhang, D.; Sun, X. A High-Efficient Method for the Amidation of Carboxylic Acids Promoted by Triphenylphosphine Oxide and Oxalyl Chloride. Heteroat. Chem. 2017, 28, No. e21364.

(24) Goodman, C. A.; Hamaker, C. G.; Hitchcock, S. R. Synthesis and Evaluation of Some Variants of the Nefkens' Reagent. Tetrahedron Lett. 2013, 54, 6012-6014.

(25) Ghosh, S. C.; Ngiam, J. S. Y.; Chai, C. L. L.; Seayad, A. M.; Dang, T. T.; Chen, A. Iron-Catalyzed Efficient Synthesis of Amides from Aldehydes and Amine Hydrochloride Salts. Adv. Synth. Catal. 2012, 354, 1407-1412.

(26) Ren, L.; Li, X.; Jiao, N. Dioxygen-Promoted Pd-Catalyzed Aminocarbonylation of Organoboronic Acids with Amines and CO: A Direct Approach to Tertiary Amides. Org. Lett. 2016, 18, 5852-5855.

(27) Das, S.; Join, B.; Junge, K.; Beller, M. A General and Selective Copper-Catalyzed Reduction of Secondary Amides. Chem. Commun. 2012, 48, 2683-2685.

(28) Qian, H.; Widenhoefer, R. A. Platinum-Catalyzed Intermolecular Hydroamination of Vinyl Arenes with Carboxamides. Org. Lett. 2005, 7, 2635-2638.

(29) Bakhoda, M.; Jiang, Q.; Badiei, Y. M.; Bertke, J. A.; Cundari, T. R.; Warren, T. H. Copper-Catalyzed C(sp3)-H Amidation: Sterically Driven Primary and Secondary $\mathrm{C}-\mathrm{H}$ Site-Selectivity. Angew. Chem., Int. Ed. 2019, 131, 3459-3463.

(30) Wu, J.-W.; Wu, Y.-D.; Dai, J.-J.; Xu, H.-J. Benzoic AcidCatalyzed Transamidation Reactions of Carboxamides, Phthalimide, Ureas and Thioamide with Amines. Adv. Synth. Catal. 2014, 356, 2429-2436.

(31) Vollmar, A.; Dunn, M. S. A Convenient Synthesis of $t$-Alkyl Esters of Amino Acids ${ }^{1 a}$. J. Org. Chem 1960, 25, 387-390.

(32) Rao, Y.; Li, X.; Danishefsky, S. J. Thio FCMA Intermediates as Strong Acyl Donors: A General Solution to the Formation of Complex Amide Bonds. J. Am. Chem. Soc. 2009, 131, 12924-12926.

(33) Efremoy, D. A.; Oberlander, E. A.; Tebby, J. C.; Zavlin, P. M.; Gribanov, A. V. Phosphorylation of Organic Compounds by Phosphoric Anhydride. Part 1. Phosphorylated Benzanilides. J. Chem. Soc., Perkin Trans. 1994, 1, 2443-2448.

(34) Meng, G.; Lei, P.; Szostak, M. A General Method for Two-Step Transamidation of Secondary Amides Using Commercially Available, Air- and Moisture-Stable Palladium/NHC (N-Heterocyclic Carbene) Complexes. Org. Lett. 2017, 19, 2158-2161.

(35) Wang, Z.; Kuninobu, Y.; Kanai, M. Molybdenum-Mediated Desulfurization of Thiols and Disulfides. Synlett 2014, 25, 18691872.

(36) Ran, L.; Ren, Z.-H.; Wang, Y. Y.; Guan, Z. H. PalladiumCatalyzed Aminocarbonylation of Aryl Iodides with Amides and Nalkyl Anilines. Chem. - Asian J. 2014, 9, 577-583.

(37) Mane, R. S.; Bhanage, B. M. Pd/C-Catalyzed Aminocarbonylation of Aryl Iodides via Oxidative $\mathrm{C}-\mathrm{N}$ Bond Activation of Tertiary Amines to Tertiary Amides. J. Org. Chem. 2016, 81, 12231228

(38) Muthaiah, S.; Ghosh, S. C.; Jee, J.-E.; Chen, C.; Zhang, J.; Hong, S. H. Direct Amide Synthesis from Either Alcohols or Aldehydes with Amines: Activity of $\mathrm{Ru}(\mathrm{II})$ Hydride and $\mathrm{Ru}(0)$ Complexes. J. Org. Chem. 2010, 75, 3002-3006.

(39) Ghosh, S. C.; Ngiam, J. S. Y.; Seayad, A. M.; Tuan, D. T.; Chai, C. L. L.; Chen, A. Copper-Catalyzed Oxidative Amidation of Aldehydes with Amine Salts: Synthesis of Primary, Secondary, and Tertiary Amides. J. Org. Chem. 2012, 77, 8007-8015.

(40) Li, J.; Xu, F.; Zhang, Y.; Shen, Q. Heterobimetallic Lanthanide/ Sodium Phenoxides: Efficient Catalysts for Amidation of Aldehydes with Amines. J. Org. Chem. 2009, 74, 2575-2577.

(41) Jakobsson, J. E.; Grønnevik, G.; Rafique, W.; Hartvig, K.; Riss, P. J. Formamide as an Unconventional Amine Protecting Group for PET Radiochemistry. Eur. J. Org. Chem. 2018, 2018, 3701-3704.
(42) Ren, W.; Yamane, M. Carbamoylation of Aryl Halides by Molybdenum or Tungsten Carbonyl Amine Complexes. J. Org. Chem. 2010, 75, 3017-3020.

(43) Achar, T. K.; Mal, P. Radical-Induced Metal and Solvent-Free Cross-Coupling Using TBAI-TBHP: Oxidative Amidation of Aldehydes and Alcohols with $\mathrm{N}$-Chloramines via $\mathrm{C}-\mathrm{H}$ Activation. J. Org. Chem. 2015, 80, 666-672.

(44) Howard, E.-L.; Guzzardi, N.; Tsanova, V. G.; Stika, A.; Patel, B. Highly Efficient Copper-Catalyzed Amidation of Benzylic Hydrocarbons Under Neutral Conditions. Eur. J. Org. Chem. 2018, 2018, 794-797.

(45) Wu, H.; Kelley, C. J.; Pino-Figueroa, A.; Vu, H. D.; Maher, T. J. Macamides and their Synthetic Analogs: Evaluation of in vitro FAAH inhibition. Bioorg. Med. Chem. 2013, 21, 5188-5197.

(46) Liu, Y.; Shi, S.; Achtenhagen, M.; Liu, R.; Szostak, M. MetalFree Transamidation of Secondary Amides via Selective N-C Cleavage under Mild Conditions. Org. Lett. 2017, 19, 1614-1617.

(47) Ashraf, Z.; Mahmood, T.; Hassan, M.; Afzal, S.; Rafique, H.; Afzal, K.; Latip, J. Dexibuprofen Amide Derivatives as Potential Anticancer Agents: Synthesis, in silico Docking, Bioevaluation, and Molecular Dynamic Simulation. Drug Des., Dev. Ther. 2019, 13, $1643-1657$.

(48) Opie, C. R.; Noda, H.; Shibasaki, M.; Kumagai, N. All NonCarbon $\mathrm{B}_{3} \mathrm{NO}_{2}$ Exotic Heterocycles: Synthesis, Dynamics, and Catalysis. Chem. - Eur. J. 2019, 25, 4648-4653.

(49) Phukan, K. Regioselective $N$-acylation of Heterocyclic Amines under Dry conditions Catalyzed by a Natural Clay. Int. J. Appl. Biol. Pharm. Technol. 2014, 5, 171-175.

(50) Li, G.; Arisawa, M.; Yamaguchi, M. Rhodium-Catalyzed Synthesis and Reactions of N-Acylphthalimides. Asian J. Org. Chem. 2013, 2, 983-988. 